\title{
Processes affecting dissolved iron across the Subtropical North Atlantic: a model study
}

\author{
Anna Pagnone ${ }^{1}$ (I) $\cdot$ Christoph Völker ${ }^{1} \cdot$ Ying Ye $^{1}$
}

Received: 23 January 2019 / Accepted: 2 July 2019 / Published online: 26 July 2019

(C) The Author(s) 2019

\begin{abstract}
Trace metal measurements in recent years have revealed a complex distribution of dissolved iron $(\mathrm{dFe})$ in the ocean that models still struggle to reproduce. The GEOTRACES section GA03 across the subtropical North Atlantic was chosen to study the driving processes involved in the Fe cycle in the region. Here, field observations found elevated dFe near the surface under the Saharan dust plume, a strong $\mathrm{dFe}$ minimum below the mixed layer depth, a maximum at the oxygen minimum zone near the African shelf, a hydrothermal maximum near the Mid Atlantic Ridge and lower dFe values in the deep eastern basin than in the west. We show that several of these features can be understood and be reproduced in models when they take into account scavenging on dust particles and phytoplankton, a variable ligand concentration and a hydrothermal $\mathrm{dFe}$ source. By doing so in a sequence of parameterisation changes, we are able to relate physical and biological processes, as well as internal and external $\mathrm{dFe}$ sources to observed features of the dFe distribution. In agreement with the observations, the additional scavenging on dust generates lower $\mathrm{dFe}$ concentrations in the deep eastern basin while the new ligand distribution results in a $\mathrm{dFe}$ maximum in the intermediate waters in the east basin and moderates the deep $\mathrm{dFe}$ gradient between the eastern and western basins.
\end{abstract}

Keywords Dissolved iron $\cdot$ North Atlantic $\cdot$ Biogeochemical model $\cdot$ Scavenging $\cdot$ Remineralisation $\cdot$ Ligands

\section{Introduction}

Iron $(\mathrm{Fe})$ is an essential micronutrient for phytoplankton used to transfer electrons in key processes including photosynthesis, respiration, chlorophyll production and carbon and nitrogen fixation (Raven et al. 1999). Thus, Fe influences the marine biology from phytoplankton growth rate and community structure to higher trophic levels (Martin et al. 1994; Boyd et al. 2000; de Baar et al. 2005; Marchetti et al. 2006; Nicol et al. 2010). Spatially, Fe regulates primary production in more than

Responsible Editor: Jörg-Olaf Wolff

Electronic supplementary material The online version of this article (https://doi.org/10.1007/s10236-019-01288-w) contains supplementary material, which is available to authorized users.

Anna Pagnone

Anna.Pagnone@awi.de

1 Alfred Wegener Institute Helmholtz Centre for Polar and Marine Research, Am Handelshafen 12, 27570 Bremerhaven, Germany
$25 \%$ (de Baar et al. 2005) and up to possibly 50\% (Moore et al. 2001; Boyd and Ellwood 2010) of the world's oceans. The equatorial Pacific, the subpolar North Pacific and the Southern Ocean are the regions where biological productivity is mostly affected by the lack of Fe. Therefore, the global marine carbon drawn-down is significantly affected by Fe, making Fe one of the drivers of the oceanic carbon pump and inducing feedback effects on climate.

Most phytoplankton groups can only transport dissolved iron $(\mathrm{dFe})$ over their cellular membrane, and many species have evolved intricate transporter systems for doing so (e.g. Lis et al. 2014). The cycling and distribution of $\mathrm{dFe}$ in the ocean is regulated by chemical, physical and biological processes. The main external inputs of $\mathrm{dFe}$ to the ocean are atmospheric dust deposition (e.g. Mahowald et al. 2005; Jickells et al. 2005), fluxes from reducing sediments (e.g. Elrod et al. 2004) and hydrothermal vents (e.g. Resing et al. 2015). Furthermore, Fe is introduced by river and groundwater erosion and discharge (e.g. Hunter et al. 1997) and by volcanic ashes (e.g. Hamme et al. 2010). In polar regions, glacial, iceberg (e.g. Raiswell et al. 2008) and sea ice (e.g. Lannuzel et al. 2008) meltwater are sources of $\mathrm{Fe}$. Fe enters its biological cycle through 
phytoplankton uptake, is transferred within the food web and is remineralised by heterotrophic organisms at depth. Unlike other nutrients, $\mathrm{dFe}$ is additionally removed by scavenging on settling particles and vertical export of biogenic material from the water column (e.g. Balistrieri et al. 1981), due to its extremely low solubility at seawater $\mathrm{pH}$ in the presence of oxygen (Liu and Millero 2002). Ligands keep $\mathrm{Fe}$ in the dissolved phase (e.g. Gledhill and Buck 2012) to some extent mitigating its low inorganic solubility. Physical transport of $\mathrm{dFe}$ (and iron-binding ligands) by ocean currents, i.e. vertical mixing, upwelling of Fe-rich water masses or transport of specific ligand signatures, also influences the dFe distribution.

Large improvements have been made in the last decades in describing the global dFe distribution, and partly also that of organic Fe-binding ligands. The efforts of GEOTRACES, that have led to the 2017 IDP (Schlitzer et al. 2018), have also revealed the importance of many new processes, such as the strong influence of hydrothermal vents on deep-sea $\mathrm{dFe}$ distributions.

However, many important processes affecting the $\mathrm{Fe}$ cycle are not well constrained quantitatively. Important examples are the strength of $\mathrm{Fe}$ sources to the ocean or the rate at which $\mathrm{dFe}$ is lost from the system through scavenging. Consequently, global biogeochemical models still differ much in their description of the marine Fe cycle, resulting in residence time estimates for $\mathrm{dFe}$ that vary over more than one order of magnitude (Tagliabue et al. 2016) and often in a much too homogeneous distribution of $\mathrm{dFe}$ in the deep ocean. The details of the distribution of $\mathrm{dFe}$ concentration that are obtained with GEOTRACES implicitly contain a wealth of information that can be used to constrain the quantitative representation of processes when combined with systematic parameter studies.

In this paper, we try to understand which processes determine the dFe distribution in the Subtropical North Atlantic Ocean. The relevant local processes are scavenging on biogenic and lithogenic particles, biological uptake, export and remineralisation. We have picked the GEOTRACES GA03 (Boyle et al. 2015) cruise leg from Bermuda to Cape Verde as our study area. This region was chosen because it is a place of very intensive Fe cycling due to strong dust input and the flourishing biological activity in the Mauritanian upwelling region. Here, the processes of interest are more pronounced compared with other regions. In this processoriented study on the GA03 cruise leg, we show how several details of the dFe distribution can be reproduced by introducing new processes and by changing existing parameterisations of processes affecting the Fe cycle. The final model includes the effects of scavenging on dust and non-sinking biogenic particles, a non-constant ligand concentration and, for completeness, a hydrothermal dFe source. For better understanding, we present this output of a fairly extensive parameter study by selecting only a simple sequence of steps in changing the model parameters that lead from our initial model setup to a final one. This presentation allows to discuss the contribution of the individual processes and parameterisation changes to the final outcome. As the $\mathrm{Fe}$ system reacts non-linearly to the parameterisation changes however, the magnitude of the changes in $\mathrm{dFe}$ distribution in the intermediate steps-but not in the final outcomeis somewhat dependent on the sequence of changes. The succession of refinements intends to disclose the role of different processes in controlling the distribution of $\mathrm{dFe}$ and their importance in biogeochemical models.

\section{The GA03 section}

The GEOTRACES GA03 cruise leg (Boyle et al. 2015) from Bermuda to Cape Verde took place in November 2011. The aim of the cruise was to document the distribution of trace elements and isotopes in the region and to diagnose the nature of the controlling biogeochemical and physical processes. We focus on the dFe distribution (Sedwick et al. 2015) (Fig. 1) in the open ocean from station USGT11-10 to station USGT11-24 (Fig. S1 in Online Resource).

The $\mathrm{dFe}$ concentrations (Fig. 1) within the surface mixed layer are high, ranging between 0.37 and $0.98 \mathrm{nmol} \mathrm{L}^{-1}$ (or equivalently $\mu \mathrm{mol} \mathrm{m}^{-3}$ ), caused by the North African dust flux (Hatta et al. 2015). The aerosol $\mathrm{Fe}$ from Saharan dust is predominantly released in the colloidal phase, having important implications for $\mathrm{dFe}$ availability to phytoplankton (Fitzsimmons et al. 2015b). This appears to be representative of $\mathrm{dFe}$ in the tropical and subtropical surface Atlantic underlying the North African dust plume (Bergquist et al. 2007; Fitzsimmons et al. 2015a).

Across the gyre (Fig. 1), dFe displays a pronounced concentration minimum in the lower euphotic zone at the depth of the deep chlorophyll maximum (DCM). Such features have been previously reported in the subtropical and tropical North Atlantic (Sedwick et al. 2005; Bergquist and Boyle 2006), and are supposedly caused by removal via biological uptake and particle scavenging (Fitzsimmons et al. 2015b; Sedwick et al. 2015).

In the intermediate waters at station USGT11-24 (Fig. 1), no correlation between $\mathrm{dFe}$ and dissolved manganese was found, excluding sedimentary $\mathrm{Fe}$ from being the main source (Hatta et al. 2015). This finding was also supported by $\delta^{56} \mathrm{Fe}$ measurements in Conway and John (2014). The correlation with the apparent oxygen utilisation (AOU) implies that the $\mathrm{dFe}$ maximum is here strongly associated with an addition of $\mathrm{Fe}$ via remineralisation alone (Hatta et al. 2015) (distributions of AOU and dissolved oxygen were reported in Jenkins et al. 2015). Model experiments by Pham and Ito (2018) argue that the intermediate water 
Fig. 1 Measured dFe along GA03 (Sedwick et al. 2015)

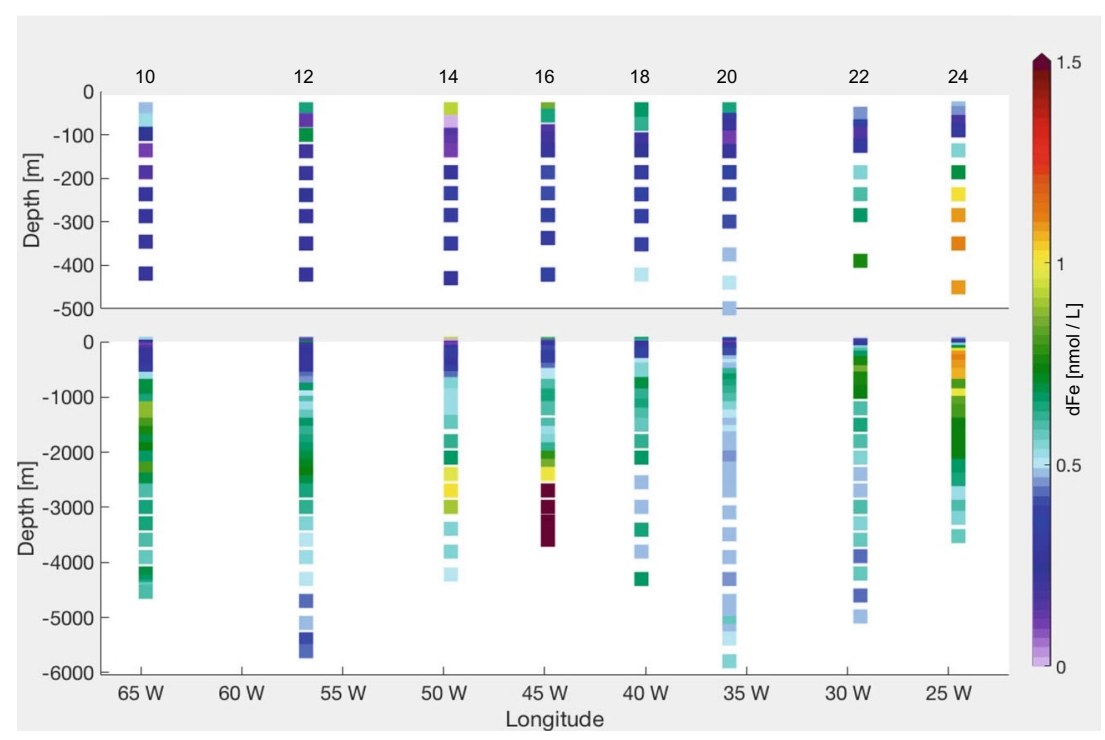

$\mathrm{dFe}$ maxima are formed by the simultaneous release of scavenged $\mathrm{Fe}$ and ligands from organic particles.

Along the western edge of the transect (Fig. 1), waters are enriched in $\mathrm{dFe}$ due to $\mathrm{Fe}$ advected from the North American continental shelf as part of the Upper Labrador Sea Water (Hatta et al. 2015) and are probably due to sedimentary resuspension. Below the thermocline, these elevated concentrations extend eastward beyond Bermuda.

In the intermediate and deep waters, the observations show a gradient between the east and the west basins, the latter having higher $\mathrm{dFe}$ concentrations (Fig. 1).

A large dFe anomaly with a concentration of up to $68 \mathrm{nmol} \mathrm{L}^{-1}$ is observed at station USGT11-16 directly over a hydrothermal site. The hydrothermal signal extends at $2000-4000 \mathrm{~m}$ depth at least $500 \mathrm{~km}$ west of the Mid Atlantic Ridge (MAR) between $40^{\circ} \mathrm{W}$ and $50^{\circ} \mathrm{W}$, with concentrations up to $1.13 \mathrm{nmol} \mathrm{L}^{-1}$, demonstrating that hydrothermalism contributes to the $\mathrm{Fe}$ pool in the deep ocean (Hatta et al. 2015).

\section{The model and its structure}

In the model, the distribution of $\mathrm{dFe}$ is calculated from mass balance equations which take into account ocean circulation, the internal biogeochemical cycling of $\mathrm{dFe}$ and external $\mathrm{dFe}$ sources. The ocean circulation model that is used to calculate advective and diffusive tracer transport is the General Circulation Model of the Massachusetts Institute of Technology (MITgcm) (Marshall et al. 1997). Our setup covers the globe from $80^{\circ} \mathrm{S}$ to $80^{\circ} \mathrm{N}$, excluding the Arctic, and has a zonal resolution of $2^{\circ}$ and a meridional resolution between $0.39^{\circ}$ and $2^{\circ}$. The thickness of 30 vertical layers increases with depth, from $10 \mathrm{~m}$ at the surface to $500 \mathrm{~m}$ below $3700 \mathrm{~m}$. The MITgcm is coupled with the marine ecosystem and biogeochemical model, REcoM2, described in detail in Hauck et al. (2013). REcoM2 describes two phytoplankton classes, diatoms and nondiatoms (small phytoplankton) with a variable elemental stoichiometry, following Geider et al. (2003) and Hohn (2009); a generic zooplankton class; and a class of organic particles sinking with vertically increasing velocity (Kriest and Oschlies 2008). The model experiments were set up with the same initial conditions and forcing fields as in Ye and Völker (2017).

\subsection{Processes}

Here, we describe the processes in our standard representation of the Fe cycle. Some of them will change in the following sections.

The evolution of the $\mathrm{dFe}$ distribution over time is described by the following differential equation:

$\frac{\partial d F e}{\partial T}=-(U+w) \cdot \nabla d F e+\nabla(k \nabla d F e)+S(d F e)$

The first two terms on the right-hand side of Eq. 1 describe the physical transport and mixing by the system. $S(\mathrm{dFe})$ is the sum of all internal dFe sources and sinks (see Table 1 for symbol description):

$$
\begin{aligned}
S(d F e)= & q^{F e}\left(\left(r_{p h y}-p_{p h y}\right) \cdot N_{p h y}+\left(r_{d i a}-p_{\text {dia }}\right) \cdot N_{\text {dia }}\right. \\
& +\left(r_{\text {het }}-\varepsilon_{\text {het }}^{N}\right) \cdot N_{\text {het }} \\
& \left.+\rho_{N_{\text {det }}} \cdot f_{T} \cdot N_{\text {det }}\right)-k_{\text {scav }}^{F e} \cdot C_{\text {det }} \cdot F e^{\prime}
\end{aligned}
$$

$\mathrm{dFe}$ is released by phytoplankton during respiration and by heterotrophs during respiration and excretion. Another internal source is remineralisation of sinking organic particles. $\mathrm{dFe}$ is drawn down by uptake of phytoplankton 
Table 1 Table of parameters

\begin{tabular}{|c|c|c|}
\hline Symbol & Parameter & Unit \\
\hline$U$ & Advection velocity & m day $^{-1}$ \\
\hline$w$ & Sinking velocity & $\mathrm{m} \mathrm{day}^{-1}$ \\
\hline$k$ & Diffusivity & $m^{2}$ day $^{-1}$ \\
\hline$F$ & Dust flux & $\mathrm{mg} \mathrm{m}^{2} \mathrm{day}^{-1}$ \\
\hline$r_{F e}$ & Iron in dust & $\mu \mathrm{mol} \mathrm{Fe} \mathrm{\textrm {mg } ^ { - 1 }}$ \\
\hline sol & Solubility & - \\
\hline$d^{N}$ & Remineralisation rate of sediment organic $\mathrm{N}$ & day $^{-1}$ \\
\hline$q_{B}^{F e}$ & Benthic Fe:N ratio & $\mu \mathrm{mol} \mathrm{Fe} \mathrm{mmol} \mathrm{N}^{-1}$ \\
\hline$q^{F e}$ & Fe: $\mathrm{N}$ ratio & $\mu \mathrm{mol} \mathrm{Fe} \mathrm{mmol} \mathrm{N}^{-1}$ \\
\hline$r_{p h y / d i a / h e t}$ & Phytoplankton/diatom/heterotroph respiration & day $^{-1}$ \\
\hline$p_{p h y / d i a}$ & Phytoplankton/diatom $\mathrm{N}$ uptake rate & day $^{-1}$ \\
\hline$N_{p h y / d i a / h e t / d e t / s e d}$ & Phytoplankton/diatom/heterotroph/detritus/sediment N & $\mathrm{mmol} \mathrm{N} \mathrm{m}^{-3}$ \\
\hline$C_{p h y / d i a / d e t}$ & Phytoplankton/diatom/detritus C & $\mathrm{mmol} \mathrm{C} \mathrm{m}^{-3}$ \\
\hline$\varepsilon_{\text {het }}^{N}$ & Heterotroph excretion & day $^{-1}$ \\
\hline$\rho_{N_{\text {det }}}$ & Remineralisation rate & day $^{-1}$ \\
\hline$f_{T}$ & Temperature-dependent Arrhenius function & - \\
\hline$k_{\text {scav }}^{F e}$ & Scavenging rate & $\mathrm{mmol} \mathrm{C} \mathrm{m}^{-3} \mathrm{day}^{-1}$ \\
\hline$k_{\text {scavdust }}^{F e}$ & Lithogenic scavenging rate & $\left(\mathrm{mg} \mathrm{m}^{-3}\right)^{-1}$ day $^{-1}$ \\
\hline$F e^{\prime}$ & Free iron & $\mu \mathrm{molFe}^{-3}$ \\
\hline$P_{\text {small/large }}$ & Small/large particles & $\mathrm{mg} \mathrm{m}^{-3}$ \\
\hline
\end{tabular}

and by scavenging on sinking particles. External inputs are aeolian dust $\mathrm{Fe}$ and sedimentary Fe. The model considers neither riverine $\mathrm{Fe}$ input nor $\mathrm{dFe}$ from sea ice melting. Parameters indicating the strength of individual processes are either taken from literature or are the result of sensitivity studies of the model.

Dust deposition The aeolian $\mathrm{dFe}$ source is a field of monthly averages of dust deposition (Mahowald et al. 2005). The flux to the ocean is:

$\left.k \frac{\partial d F e}{\partial z}\right|_{z=0}=F_{d u s t} \cdot r_{F e} \cdot s o l$

The model assumes that $3.5 \%$ of dust particles consists of $\mathrm{Fe}$ and that $2 \%$ of this Fe immediately dissolves when deposited in the surface ocean.

Sediment source The sedimentary Fe source at the sea floor is given by the release of $\mathrm{dFe}$ proportional to the degradation of organic material in a homogeneous sediment layer:

$\left.k \frac{\partial d F e}{\partial z}\right|_{z=-H}=q_{B}^{F e} \cdot d^{N} \cdot P O N_{\text {sed }}$

This goes back to Elrod et al. (2004), who found a significant correlation between the $\mathrm{dFe}$ flux from the sediment and the oxidation of organic matter. Sinking biogenic particles that reach the sediment are ultimately dissolved or remineralised and returned into the water column as a normal flux, whereas the $\mathrm{dFe}$ scavenged is permanently removed.

Phytoplankton uptake In the model, the total pool of $\mathrm{dFe}$ is assumed to be bioavailable and the $\mathrm{dFe}$ uptake is proportional to nitrogen assimilation. The phytoplankton growth rate is limited by $\mathrm{dFe}$, in the form of a MichaelisMenten function, and by an intracellular nitrogen and silica quota.

Remineralisation In the first step of carbon or nitrogen remineralisation, the particulate organic matter $(\mathrm{OM})$ is transformed into dissolved OM. Bacterial degradation then breaks it into dissolved inorganic carbon or nitrogen, which are bioavailable for phytoplankton. Since $\mathrm{dFe}$ is mostly organically bound anyway, the model returns Fe directly to the dissolved pool through remineralisation of particulate $\mathrm{OM}$, with a rate of $\rho_{N_{d e t}} \cdot f_{T} \cdot N_{d e t}$.

Organic complexation The model considers two forms of $\mathrm{Fe}$ : the $\mathrm{Fe}$ bound to organic ligands, $\mathrm{FeL}$, and the free inorganic $\mathrm{Fe}, F e^{\prime}$. The $\mathrm{Fe}$ tracer in the model is the sum of the two forms $d F e=F e L+F e^{\prime} . F e^{\prime}$ is calculated as in Parekh et al. (2004) and represents only a small percentage of the total $\mathrm{dFe}$ pool. It is assumed that $\mathrm{Fe}$ and ligands are bound in a 1:1 ratio. In REcoM2, the ligand concentration is assumed constant at $1 \mu \mathrm{mol} \mathrm{m}^{-3}$ and the conditional stability constant is set to $10^{11}$. 
Table 2 Steps in model development

\begin{tabular}{lll}
\hline Model run & Process added & Remarks \\
\hline Standard & Generic dFe modelling & \\
Dust & + Scavenging on dust particles & $k_{\text {scavdust }}^{F e}=7.5 \cdot 10^{-4} /\left(\mathrm{mg} / \mathrm{m}^{3}\right) /$ day \\
AOU-Lig & + Ligands from AOU & $\mathrm{L}=(1+0.005 \cdot \mathrm{AOU}) \mathrm{nmol} \mathrm{L}$ \\
Scav Phyto & + Scavenging on phytoplankton & \\
Scav Phyto 2 & + Reduced $k_{\text {scavdust }}^{F e}$ & $k_{\text {scavdust }}^{F e}=2 \cdot 10^{-4} /\left(\mathrm{mg}^{-1} \mathrm{~m}^{3}\right) / \mathrm{day}^{-1}$ \\
VS & + Increased Det sink velocity & Velocity slope 0.0288 day $^{-1} \rightarrow 0.0432$ day $^{-1}$ \\
Hydro & + Hydrothermal Fe source & \\
\hline
\end{tabular}

Scavenging The scavenging is assumed to be proportional to the detritus carbon, thus to the mass of sinking particles, and to the $F e^{\prime}$ concentration, $k_{\text {scav }}^{F e} \cdot C_{d e t} \cdot F e^{\prime}$.

\subsection{Model experiments}

Results of the FeMIP Project show many differences between Fe cycle models (Tagliabue et al. 2016). However, some of the assumptions are similar, and the REcoM2 model shares many of them. Looking at the GA03 section, these result in an incomplete representation of the observations, where some important features of the $\mathrm{dFe}$ distribution are either not captured or their magnitude is misestimated. This may imply an inadequacy of the current Fe cycle modelling for the region in focus.

Different processes that affect the Fe cycle are often non-linearly dependent, meaning that a simple parametertuning exercise is difficult. For this reason, in the following, we show the changes in $\mathrm{dFe}$ concentration by introducing subsequently new processes in the model. Each model run was integrated for 1000 years from a state of rest. The five steps taken are from the Standard run, to the Dust run which includes scavenging on lithogenic particles, to the AOU-Lig run where a parameterisation of ligands was introduced, to the Scav Phyto run in which an additional scavenging on phytoplankton was added, to the VS run where the velocity of sinking particles is changed, to the final Hydro run which includes a hydrothermal dFe source (Table 2). The details of these changes are explained in Results (Section 4).

\section{Results}

\subsection{Standard}

In the Standard run the scavenging rate is $k_{\text {scav }}^{F e}=$ $0.02 \mathrm{mmol} \mathrm{C} \mathrm{m}^{-3} \mathrm{~d}^{-1}$. The model shows (Fig. 2) high $\mathrm{dFe}$ concentrations at the surface of the east basin (east of the MAR - east of $45^{\circ} \mathrm{W}$ ) due to strong aeolian input from the African continent. This influences the layers below until ca. $300 \mathrm{~m}$ depth. In the west basin (west of the MAR-west of $45^{\circ} \mathrm{W}$ ), we see a minimum at ca. $50 \mathrm{~m}$, which corresponds to the DCM and is an expression of biological dFe uptake. Both these features are also seen in the GEOTRACES data (Fig. 1). However, compared with the observations, the model generally overestimates $\mathrm{dFe}$. Near the American
Fig. 2 Modelled dFe along GA03 in the Standard run, with measured $\mathrm{dFe}$ values as dots

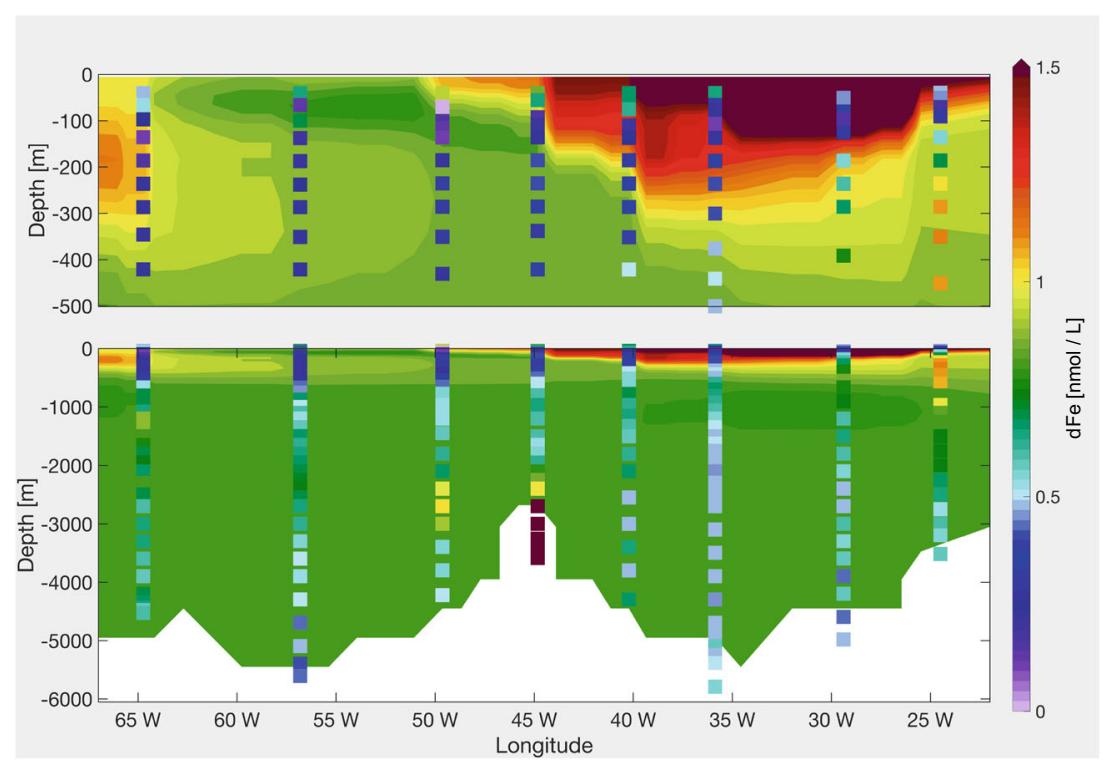


coast at $200-300 \mathrm{~m}$, a dFe maximum is observed in the model which is not seen in the data (Fig. 2). This dFe is transported north from the region off Puerto Rico. Below $500 \mathrm{~m}$, the $\mathrm{dFe}$ concentration is fairly homogenous in the model, slightly lower on the west side of the MAR. The model does not reproduce the $\mathrm{dFe}$ variability in the intermediate and deep ocean: one reason being that the hydrothermal $\mathrm{dFe}$ input is neglected here.

\subsection{Standard + dust scavenging}

In the Subtropical North Atlantic, scavenging on lithogenic particles is a major process in the Fe cycle. Ye and Völker (2017) argue that neglecting dust particles as scavengers is one main reason for overestimation of $\mathrm{dFe}$ under the Saharan dust plume. The particle dynamics in the model considers aggregation and disaggregation of fine dust particles and large organic and lithogenic particles. Scavenging now occurs on lithogenic particles as well as organic particles (2):

$\left(k_{\text {scav }}^{F e} \cdot C_{\text {det }}+k_{\text {scavdust }}^{F e} \cdot\left(P_{\text {small }}+P_{\text {large }}\right)\right) \cdot F e^{\prime}$

where $k_{\text {scavdust }}^{F e}=7.5 \cdot 10^{-4}\left(\mathrm{mg} \mathrm{m}^{-3}\right)^{-1} \mathrm{~d}^{-1}$ (Table 1). For further details, see Ye and Völker (2017).

Including removal by lithogenic particles reduces the $\mathrm{dFe}$ concentration everywhere in the transect (Fig. 3). The largest effect occurs in the water column under the dust plume where the water in the upper $100 \mathrm{~m}$ loses $30 \%$ of $\mathrm{dFe}$, whereas the intermediate and deep waters lose $70 \%$ of $\mathrm{dFe}$.

While in the Standard run the scavenging loss of surface $\mathrm{dFe}$ is limited to the upper $50 \mathrm{~m}$ and east of
Fig. 3 a Modelled dFe concentration in the Dust run along GA03, with measured $\mathrm{dFe}$ values as dots; $\mathbf{b} \mathrm{dFe}$ difference between the Standard run and the Dust run
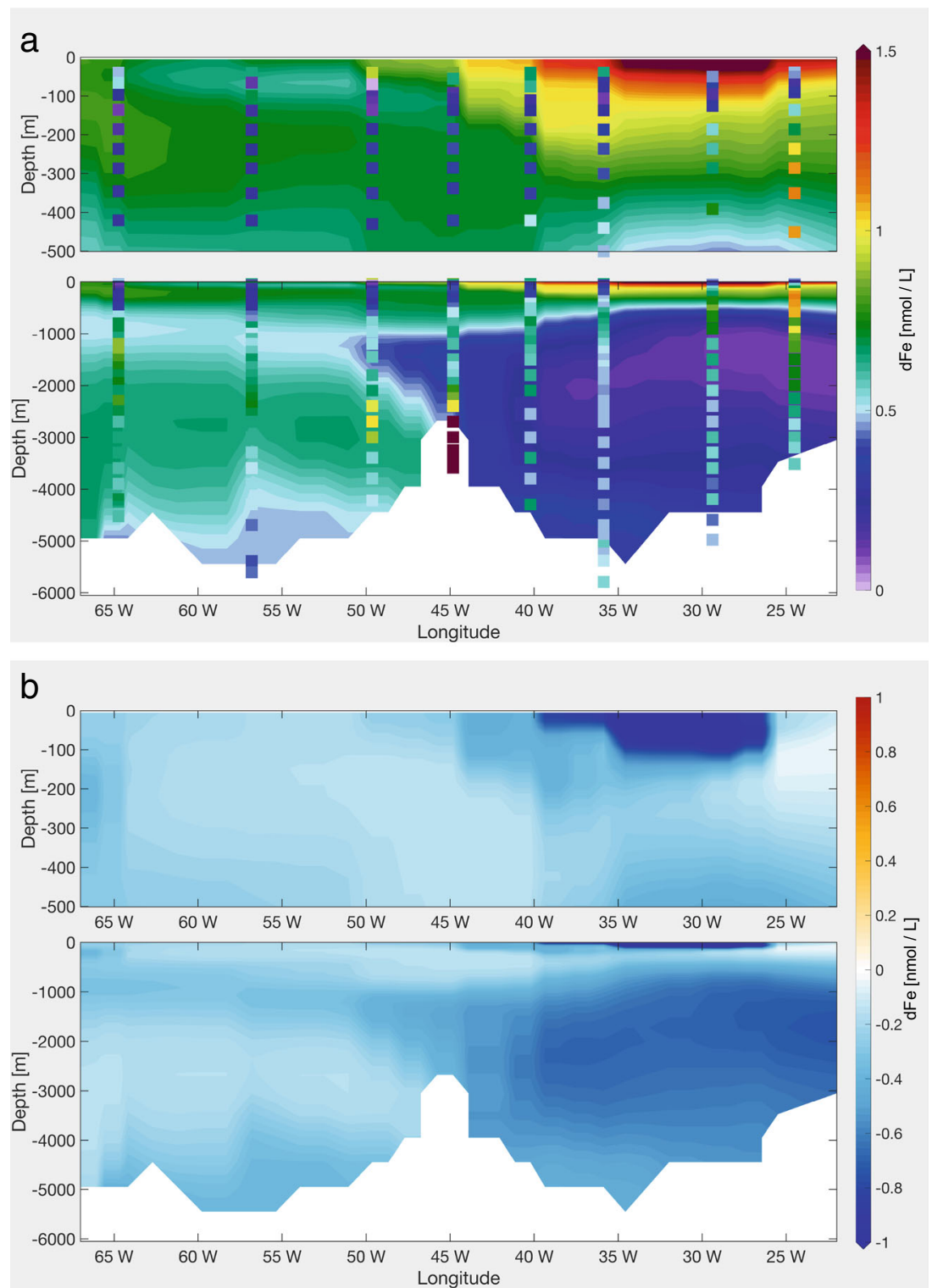
$26^{\circ} \mathrm{W}$, reaching a maximum of $4.5 \mathrm{nmol} \mathrm{L}^{-1}$ year $^{-1}$, the effect now is more widespread, reaching as far as $40^{\circ} \mathrm{W}$, and into the oligotrophic waters of the subtropical gyre at a $100-\mathrm{m}$ depth. The scavenging strength reaches here a maximum of $12 \mathrm{nmol} \mathrm{L}^{-1}$ year $^{-1}$. Consequently, the $\mathrm{dFe}$ concentration is reduced by more than $1 \mathrm{nmol} \mathrm{L}^{-1}$ between $25^{\circ} \mathrm{W}$ and $40^{\circ} \mathrm{W}$ (Fig. 3b), but it is still too high compared with the observations. Here, the biogenic and lithogenic scavenging is the most dominant process affecting $\mathrm{dFe}$ distribution compared with biological uptake and remineralisation as can be seen in the upper layers in the east basin (ED1) in Fig. S2 in Online Resource where the integrated contributions of scavenging, biological uptake and remineralisation to the $\mathrm{dFe}$ pool are shown.

Alterations in the surface dFe distribution caused by the additional scavenging onto dust particles were already observed by Ye and Völker (2017). However, the changes are not limited to the surface ocean: while the Standard run gives homogenous $\mathrm{dFe}$ concentrations below $500 \mathrm{~m}$, the scavenging on dust introduces longitudinal structure, showing a strong gradient between the east and the west basins (Fig. 3). A similar but weaker gradient was also seen in the observations (Fig. 1). dFe in the model decreases in the east basin by roughly $0.6 \mathrm{nmol} \mathrm{L}^{-1}$, and by only $0.15 \mathrm{nmol} \mathrm{L}^{-1}$ in the west basin, with the result that the $\mathrm{dFe}$ concentrations in the east basin are too low. It should be noted that here we used the same dust scavenging rate and aggregation and disaggregation coefficients as in Ye and Völker (2017). With more data for particles in different size fractions, a full sensitivity study on the aggregation and disaggregation rate could be performed.

\subsection{Standard + dust scavenging + AOU ligands}

The eastern part of the GA03 shows a dFe maximum between 300 and $600 \mathrm{~m}$ where an oxygen minimum zone (OMZ) spreads from the Mauritanian coast (Fig. 1). This pronounced OMZ has shown a correlation to the elevated $\mathrm{dFe}$ concentrations in this particular region (Rijkenberg et al. 2012). Here, remineralisation of sinking organic material releases both $\mathrm{dFe}$ and organic ligands which prevent $\mathrm{dFe}$ from scavenging removal. Previous studies also ascribed the $\mathrm{dFe}$ maximum along GA03 to remineralisation processes (Hatta et al. 2015), dissociation of adsorbed $\mathrm{Fe}$ from sinking particles and ligands from organic particles (Pham and Ito 2018).

Our model runs, however, do not reproduce this feature, despite having a strong remineralisation of $\mathrm{dFe}$. Based on the strong correlation between $\mathrm{AOU}$ and $\mathrm{dFe}$ in GA03 (Hatta et al. 2015), we decided to introduce a ligand parameterisation based on AOU in a similar way to Misumi et al. (2013), who applied a linear relationship between AOU and the weak binding ligands $\mathrm{L}_{2}$. Comparing the
AOU values from the World Ocean Atlas (Garcia et al. 2010a) with the ligand data along GA03 (Buck et al. 2015), we notice a correlation between AOU and the strong binding ligands $\mathrm{L}_{1}$, rather than $\mathrm{L}_{2}$. The Pearson correlation coefficient is 0.45 when using ligand data between 200 and $3000 \mathrm{~m}$ depth. This emphasises that oxidation of $\mathrm{OM}$ is an important source of ligands. Instead of using a constant ligand concentration of $1 \mathrm{nmol} \mathrm{L}^{-1}$, we adapted the parameterisation of Misumi et al. (2013) to represent the abundance of total ligands in the $A O U$ - Lig run:

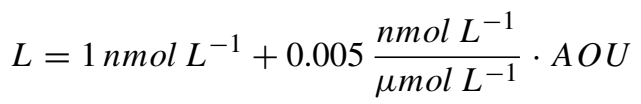

where 0.005 is the slope of the fit between $\mathrm{AOU}$ and $\mathrm{L}_{1}$.

The new ligand distribution changes in a similar way to $\mathrm{dFe}$ in Fig. 4. It is reduced to ca. $0.95 \mathrm{nmol} \mathrm{L}^{-1}$ at the surface; east of $30^{\circ} \mathrm{W}$ between 200 and $1000 \mathrm{~m}$ the concentration is now higher than $2 \mathrm{nmol} \mathrm{L}^{-1}$; a tongue of ca. $1.5 \mathrm{nmol} \mathrm{L}^{-1}$ ligand's concentration extends at $1000 \mathrm{~m}$ from the east to the west; the average concentration below $2000 \mathrm{~m}$ in the east basin is $1.5 \mathrm{nmol} \mathrm{L}^{-1}$, while in the west basin it is $1.3 \mathrm{nmol} \mathrm{L}^{-1}$. Since the ligand concentration becomes higher than $1 \mathrm{nmol} \mathrm{L}^{-1}$ everywhere but at the surface, we see a lower scavenging loss and an average increase of $\mathrm{dFe}$ concentrations of $0.3 \mathrm{nmol} \mathrm{L}^{-1}$ along the transect (Fig. 4). East of $26^{\circ} \mathrm{W}$, at the depth of the AOU maximum, the $\mathrm{dFe}$ concentrations are on average $0.8 \mathrm{nmol} \mathrm{L}^{-1}$ higher than the Dust run, stretching vertically from the surface to $500 \mathrm{~m}$. Below $1000 \mathrm{~m}$, the increase of $\mathrm{dFe}$ is $150 \%$ in the east basin, which had before a too low iron concentration, and only of $50 \%$ in the west basin.

A limitation of this ligand parameterisation is that it can not be applied globally. This parameterisation is an approximation for younger water masses like the deep Atlantic Ocean, but leads to too high ligand concentrations in older water masses such as in the deep Pacific Ocean (not shown) (Section 5.4).

\subsection{Standard + dust scavenging + AOU ligands + phytoplankton scavenging}

A strong subsurface $\mathrm{dFe}$ minimum occurs within the centre of the North Atlantic subtropical gyre and stretches across the Atlantic basin. The minimum at the DCM between 100 and $200 \mathrm{~m}$ is argued in the literature to be caused by combined $\mathrm{dFe}$ scavenging and biological uptake (Hatta et al. 2015). As described in Section 4.1, the Standard run does reproduce a subsurface minimum; it is however not pronounced enough. Since the modelled primary production in this region is comparable with observations, we take a closer look at the scavenging process. Phytoplankton can be considered as small particles which offer a surface to 
Fig. 4 a Modelled dFe along GA03 in the AOU-Lig run, with measured $\mathrm{dFe}$ values as dots; $\mathbf{b}$ $\mathrm{dFe}$ difference between the Dust run and the AOU-Lig run. The contour lines show the new ligand concentration $\left(n \mathrm{~mol} \mathrm{~L}^{-1}\right)$
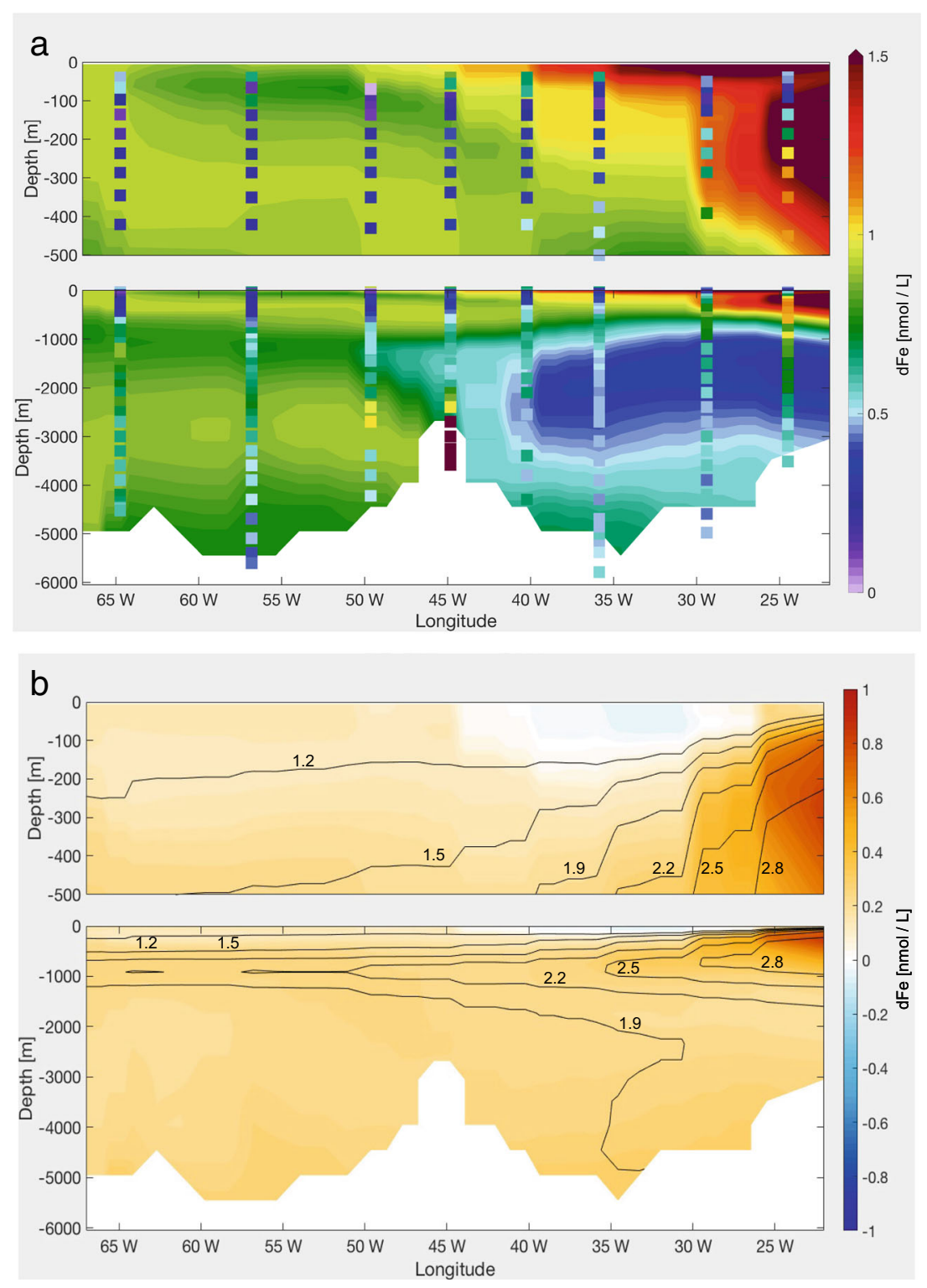

scavenge dFe (Hudson and Morel 1989). In Eq. 2, the scavenging term is (Table 1):

$\left(k_{\text {scav }}^{F e} \cdot\left(C_{\text {det }}+C_{\text {phy }}+C_{\text {dia }}\right)+k_{\text {scavdust }}^{F e} \cdot\left(P_{\text {small }}+P_{\text {large }}\right)\right) \cdot F e^{\prime}$

The $\mathrm{dFe}$ concentration is reduced everywhere along GA03 (Fig. 5), with the major effect in the upper $100 \mathrm{~m}$, with the maximal $\mathrm{dFe}$ loss of $0.5 \mathrm{nmol} \mathrm{L}^{-1}$. Here, introducing scavenging on phytoplankton leads to a scavenging increase between 50 and $300 \%$ between $45^{\circ} \mathrm{W}$ and $65^{\circ} \mathrm{W}$. Though scavenging on phytoplankton is limited to the euphotic zone, we also observe a decrease of $\mathrm{dFe}$ in the deeper layers. This is caused by a decrease in the pre-formed $\mathrm{dFe}$ concentration in the water mass formation regions.
To prevent an overly low $\mathrm{dFe}$ at depth, we reduce the scavenging rate of dust particles, $k_{\text {scavdust }}^{F e}$ to $2 \cdot 10^{-4}\left(\mathrm{mg} \mathrm{m}^{-3}\right)^{-1} \mathrm{day}^{-1}$ (Scav Phyto 2 run) (Fig. 5c). This mainly affects the deep east basin, where the average concentration of $0.3 \mathrm{nmol} \mathrm{L}^{-1}$ is increased to ca. $0.5 \mathrm{nmol} \mathrm{L}^{-1}$, since more $\mathrm{dFe}$ sinks to the deep ocean by reducing the scavenging under the dust plume. The west basin is almost unchanged due to the limited influence of dust in this region.

The observed $\mathrm{dFe}$ shows very low concentrations also below the DCM, where the $\mathrm{dFe}$ concentration is expected to increase again due to remineralisation. The low $\mathrm{dFe}$ concentrations extend down to $700 \mathrm{~m}$ (Fig. 1). Neither the Standard run nor the Scav Phyto 2 run reproduces this feature; the reason is discussed in Section 5.3. 
Fig. 5 a Modelled dFe the

GA03 in the Scav Phyto run,

with measured $\mathrm{dFe}$ values as dots; $\mathbf{b} \mathrm{dFe}$ difference between the AOU-Lig run and the Scav Phyto run; $\mathbf{c} \mathrm{dFe}$ difference between the Scav Phyto run and the Scav Phyto 2 run
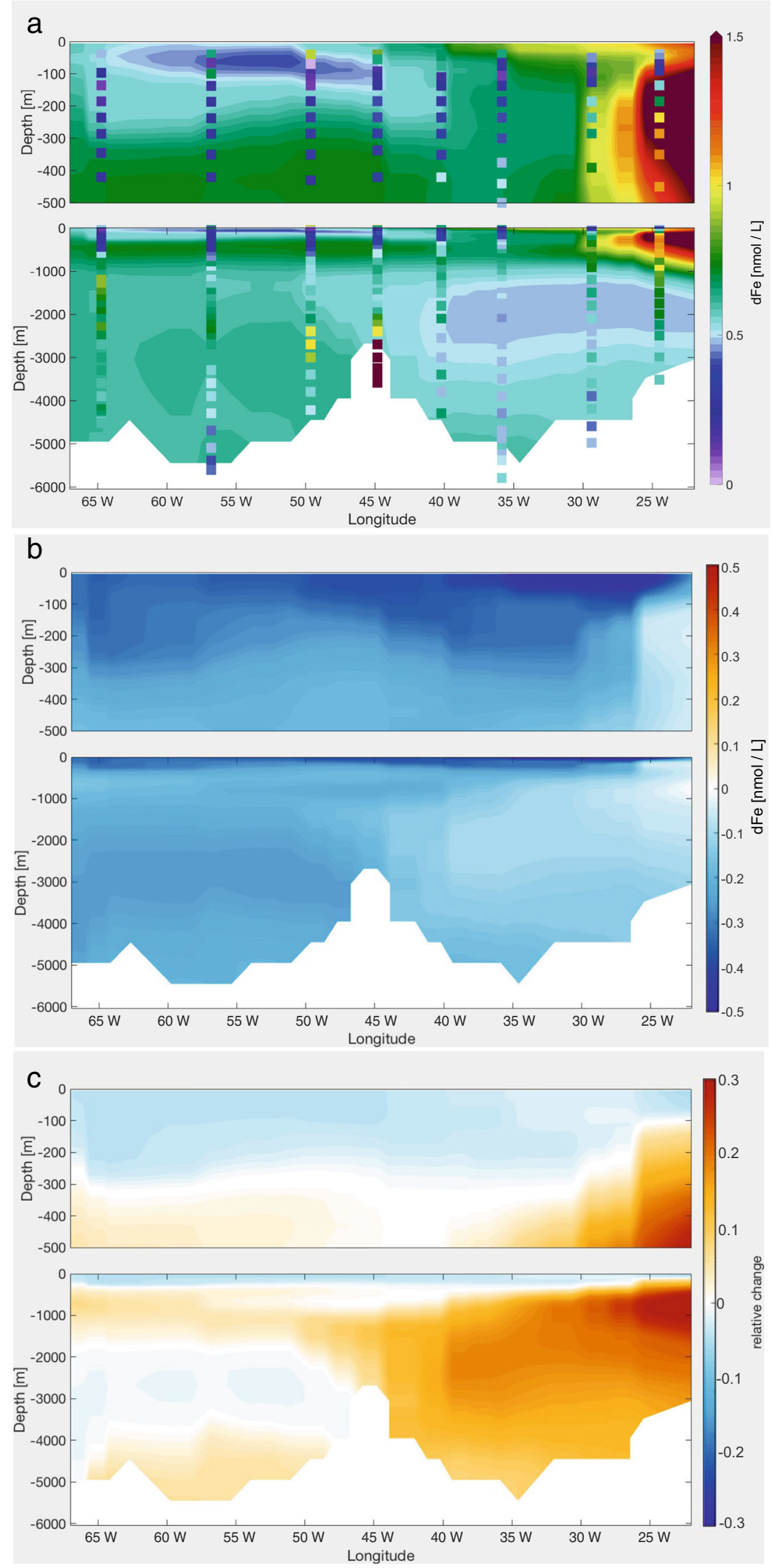


\subsection{Standard + dust Scavenging + AOU ligands + phytoplankton scavenging + increased velocity slope}

The observed intermediate water $\mathrm{dFe}$ maximum, which is mainly driven by remineralisation, is deeper compared with the modelled one. In addition, the vertical maximum of dissolved inorganic nitrogen (DIN) in the model is shallower than the observations in WOA (Garcia et al. $2010 \mathrm{~b}$ ), indicating that also the remineralisation process in the model is too shallow. The depth of remineralisation depends on how fast organic particles sink. In the model, the sinking speed of detritus is $20 \mathrm{~m} \mathrm{day}^{-1}$ at the surface and increases linearly with depth after Kriest and Oschlies (2008) with a slope of $0.0288 \mathrm{day}^{-1}$. To deepen the remineralisation flux, we increased the slope of the sinking velocity by $50 \%$, to 0.0432 day $^{-1}$, so that biogenic particles sink out of the surface, and the water column, faster.

In the upper $100 \mathrm{~m}$, this results in a slight increase of 5\% in $\mathrm{dFe}$ concentration along the transect (Fig. 6), despite an increase of scavenging and a decrease in remineralisation. The biological production in the Subtropical North Atlantic Ocean is macro-nutrient limited. Increasing the sinking velocity of particles, the residence time of organic particles in the water column is reduced and so the remineralisation of nutrients, leading to an intensified nutrient limitation of phytoplankton growth. This induces a weaker biological production, thus weaker uptake of $\mathrm{dFe}$, leaving more $\mathrm{dFe}$ in the water. At the same time, increasing the sinking velocity means that large particles remain a shorter time in the upper water column, while small particles increase due to less aggregation. The $\mathrm{dFe}$ removal by scavenging is
Fig. 6 a Modelled $\mathrm{dFe}$ along GA03 in the $V S$ run, with measured $\mathrm{dFe}$ values as dots; $\mathbf{b}$ $\mathrm{dFe}$ difference between the $S c a v$ Phyto 2 run and the VS run
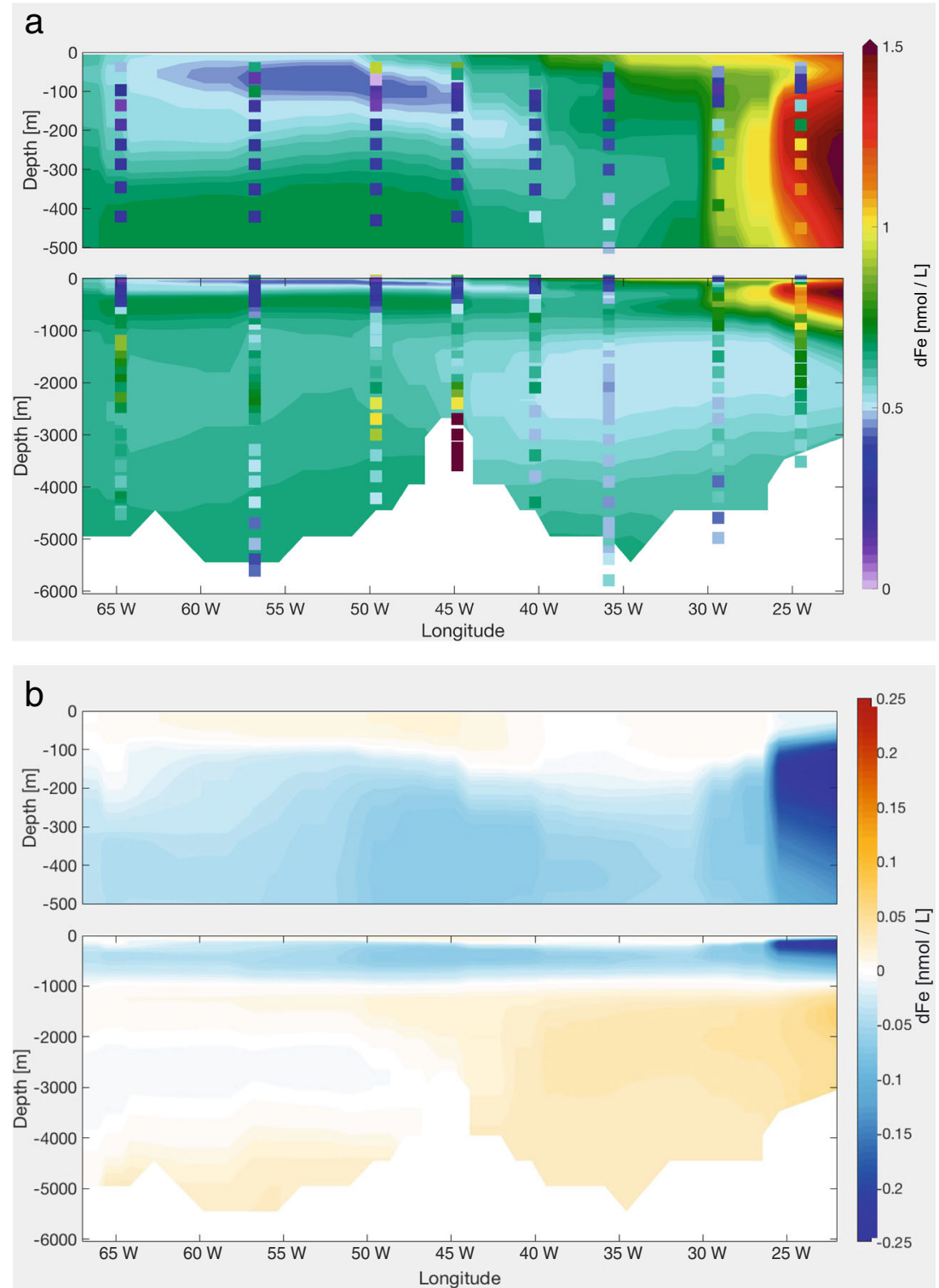
reinforced by this higher concentration of small particles. The competition of these two processes leads to different features west and east of $26^{\circ} \mathrm{W}$. West of $26^{\circ} \mathrm{W}$, the $\mathrm{dFe}$ loss term at the surface is dominated by biological uptake compared with scavenging, explaining the $\mathrm{dFe}$ increase in the upper $100 \mathrm{~m}$. On the other hand, east of $26^{\circ} \mathrm{W}$, under the dust plume, scavenging is mainly controlling $\mathrm{dFe}$ concentration. Here, the $\mathrm{dFe}$ concentration is reduced.

Between 100 and $1000 \mathrm{~m}, \mathrm{dFe}$ decreases while below it increases, both ranging from 5 to $15 \%$, with a maximal effect in the east. The mean scavenging is reduced by approximately $5 \%$ below $200 \mathrm{~m}$, except east of $26^{\circ} \mathrm{W}$ where it is reduced by $40 \%$. In general, the mean remineralisation in this run is reduced by 20 to $40 \%$ in the upper $1000 \mathrm{~m}$ (Fig. S3 and Fig. S2, e.g. ED1 and ED2), while it increases by the same amount below $1000 \mathrm{~m}$. West of $65^{\circ} \mathrm{W}$, the remineralisation increase reaches $80 \%$ (Fig. S3 and partially seen in Fig. S2, WD3). This does not only affect local dFe profiles but also the entire $\mathrm{Fe}$ cycle because of the longer residence time of $\mathrm{dFe}$.

\subsection{Standard + dust scavenging + AOU ligands + phytoplankton scavenging + increased velocity slope + hydrothermal vent}

The measurements of GA03 show a strong hydrothermal $\mathrm{dFe}$ input from the MAR at $45^{\circ} \mathrm{W}$ (Fig. 1). Though the representation of hydrothermal vents as a source of $\mathrm{dFe}$ to the deep ocean is not new (Tagliabue et al. 2010), we present the result of the Hydro run here as an additional and final step since the effect of each process investigated in this study on the dFe distribution does not add on linearly. As Tagliabue et al. (2010), we assumed proportionality of the release of $\mathrm{dFe}$ to that of ${ }^{3} \mathrm{He}$ at known position of hydrothermal vents. The distribution of hydrothermal vents used in the model includes a vent site located about $1^{\circ}$ to the west of station USGT11-16. The uncertainty of the location of hydrothermal vents and in the proportionality of $\mathrm{dFe}$ to ${ }^{3} \mathrm{He}$ has to be mentioned.

The Hydro run was started from the output of the VS run after 900 years and was then integrated for a further 100 years to include the local hydrothermal effect. The effect of the hydrothermal source of $\mathrm{dFe}$ is strongly influenced by the AOU-based ligand parameterisation, thus switching on the hydrothermal source in combination to the new ligand distribution for longer integrations leads to a nonlocal signal in our setup-in Section 5.4, this topic will be discussed.

As expected, in the model, a far field plume of high concentrations up to $0.9 \mathrm{nmol} \mathrm{L}^{-1}$ is expanding at a depth of 2000 to $3000 \mathrm{~m}$, up to $5^{\circ}$ east and $5^{\circ}$ west of the source (Fig. 7). The lateral spreading of $\mathrm{dFe}$ over large distances, which has been observed in the GEOTRACES program, has been ascribed to the concomitant release of organic ligands (e.g. Bennett et al. 2008) or the formation of microparticles which hardly sink (e.g. Yücel et al. 2011) and which possibly exchange Fe reversibly with the dissolved phase (Fitzsimmons et al. 2017). Neither of these processes is present in the model. The extremely high values observed at station USGT11-16 in the buoyant plume, up to $68 \mathrm{nmol} \mathrm{L}^{-1}$, can not be represented by models with coarse resolution, where $\mathrm{dFe}$ is homogeneously mixed in the bottom box. Such high point values are important for the first scavenging loss in the near field of vents but not for biogeochemistry at the scale of model resolution.

\section{Discussion}

The $\mathrm{dFe}$ concentrations along GA03 give indications on which processes are important in shaping its distribution in the Subtropical North Atlantic. The main features and their controlling processes can be summarised (Fig. 8a): (1) A strong aeolian deposition leads to surface $\mathrm{dFe}$ maximum; (2) in the lower euphotic zone, the dFe concentration is very low due to biological uptake and scavenging onto biogenic and lithogenic particles; (3) between 200 and $1000 \mathrm{~m}$ east of $30^{\circ} \mathrm{W}$, the elevated $\mathrm{dFe}$ concentration is determined by remineralisation and high ligand concentration; (4) at the west edge, between 200 and $700 \mathrm{~m}, \mathrm{dFe}$-poor water is advected from the north; (5) close to Bermuda, a $\mathrm{dFe}$ increase between 1000 and $2000 \mathrm{~m}$ is observed in correspondence of sedimentary $\mathrm{dFe}$-rich water transported from the Upper Labrador Sea; (6) extremely high $\mathrm{dFe}$ concentrations are found over and around the hydrothermal vents on the Mid Atlantic Ridge.

These features and processes are not well represented in our Standard run (Fig. 8b): (1) The dFe concentrations at the surface are overestimated; (2) only a much weaker $\mathrm{dFe}$ subsurface minimum is found; (3) no $\mathrm{dFe}$ maximum is reproduced close to Cap Verde between 200 and $1000 \mathrm{~m}$; (4) close to Bermuda, between 100 and $300 \mathrm{~m}$, the model features $\mathrm{dFe}$-rich water advected from the south; (5) the model does not reproduce the $\mathrm{dFe}$ variability in the intermediate and deep ocean, as below $500 \mathrm{~m}$ the $\mathrm{dFe}$ concentration is almost constant.

The steps undertaken in this study to improve the understanding of key processes as well as the model-data agreement are as follows: including scavenging by both lithogenic particles and phytoplankton (Sections 4.2, 4.4); keeping remineralised $\mathrm{dFe}$ in solution by moving from a constant ligand distribution to one which has higher ligand concentration in the OMZ (Section 4.3); deepening the $\mathrm{Fe}$ remineralisation by accelerated sinking of biogenic particles (Section 4.5); considering the hydrothermal $\mathrm{dFe}$ source (Section 4.6). 
Fig. 7 a Modelled dFe along GA03 in the Hydro run (100 years), with measured $\mathrm{dFe}$ values as dots; $\mathbf{b} \mathrm{dFe}$ difference between the $V S$ run and the Hydro run (100 years)
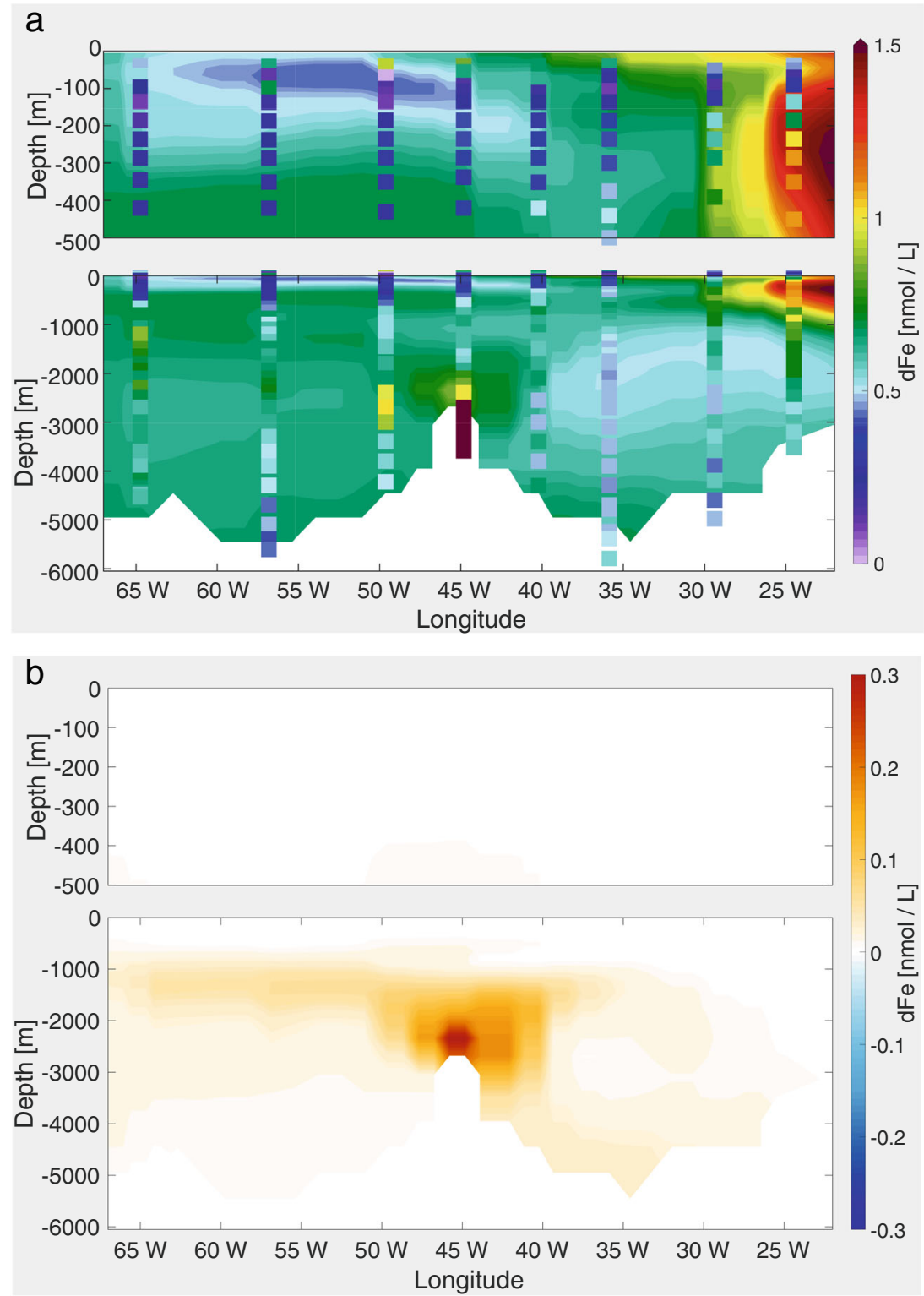

The final model setup describes the dFe distribution in the Subtropical North Atlantic more realistically (Fig. 8c). The $\mathrm{dFe}$ surface concentration is mainly regulated by dust and phytoplankton scavenging, with the major effect under the dust plume. The effect of phytoplankton scavenging is widespread and generates a subsurface dFe minimum. Relating ligand concentration to AOU increases the $\mathrm{dFe}$ concentration mostly east of $26^{\circ} \mathrm{W}$. Even though the $\mathrm{dFe}$ values shown here are too high compared with the observations (Fig. 4), with this parameterisation of ligands, we are able to reproduce the local vertical maximum. Increasing the sinking velocity of the biogenic particles, the remineralisation source of $\mathrm{dFe}$ is shifted towards depth with a decrease of $\mathrm{dFe}$ concentration between 100 and $1000 \mathrm{~m}$ and an increase below. At depth, the scavenging on dust introduces longitudinal structure which is somewhat mitigated by a gradient in ligand concentrations. The local hydrothermal input leads to high concentrations above the vent, even though not as high as in the measurements.

While Fig. 8a, b and c show the qualitative effects of each new process on the $\mathrm{dFe}$ distribution, a more quantitative approach is given in Section 1 and Fig. S2 in Online Resource.

\subsection{Statistical assessment}

We examined the Pearson correlation between the observed and modelled $\mathrm{dFe}$ at the same locations in the initial Standard run and the final Hydro run (Table 3). Taking into account the entire water column along GA03, the correlation coefficient between modelled and observed $\mathrm{dFe}$ is $R=$ -0.26 in the Standard run and it improved to $R=0.25$ 

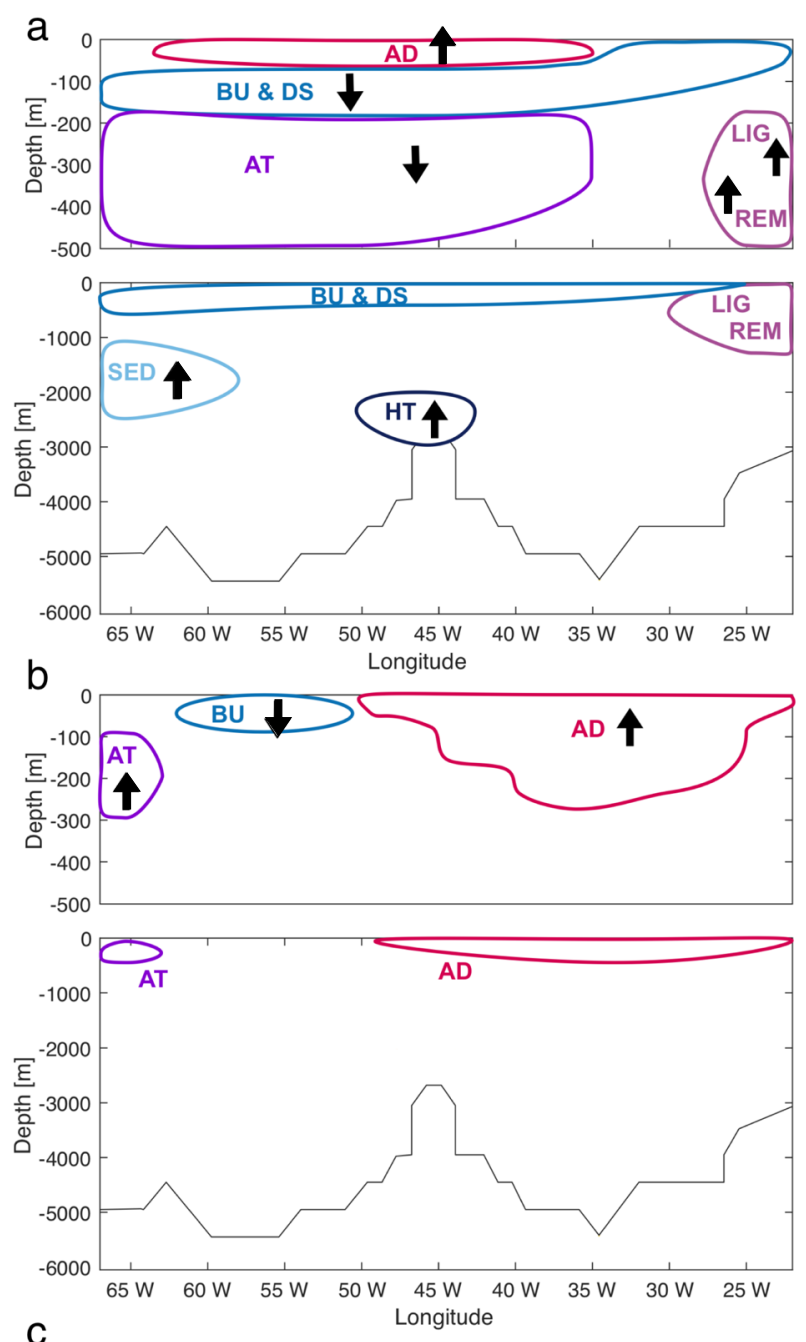

$\circ$
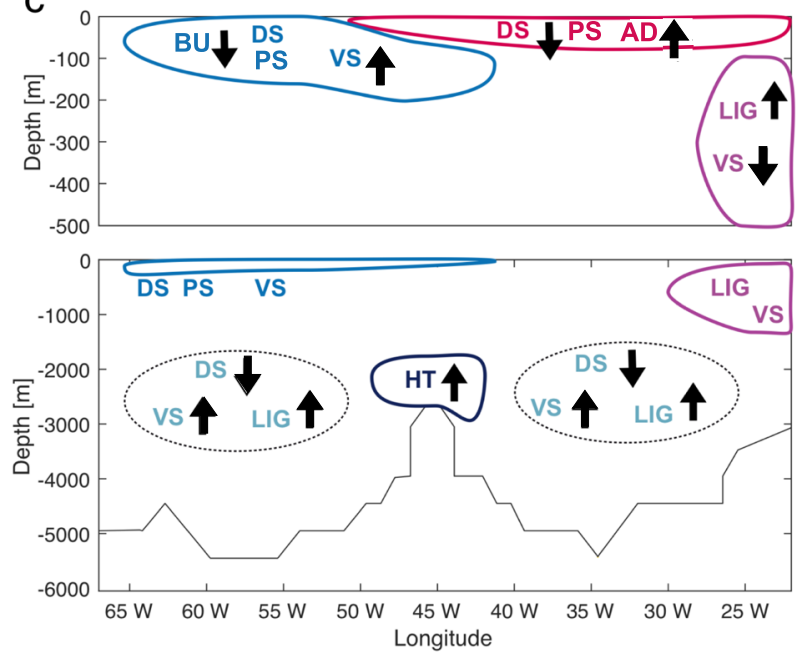

Fig. 8 Pattern of $\mathrm{dFe}$ in the observations a, in the Standard run b and in the Hydro run c. The most important processes which influence the $\mathrm{dFe}$ distribution are as follows: $\mathrm{AD}$, aeolian deposition; HT hydrothermal input; BU biological Uptake; DS dust scavenging; LIG ligand binding; REM remineralisation; SED sedimentary input; AT advective transport; PS phytoplankton scavenging; VS sinking velocity. The arrows indicate whether the process is a source or a sink of $\mathrm{dFe}$ in the Hydro run. The mean bias against observations is reduced from 0.39 to $0.11 \mathrm{nmol} \mathrm{L}^{-1}$.

To better analyse the local effects of the processes, we split the section into six sectors by considering east and west basins (east and west of $45^{\circ} \mathrm{W}$ ), and by defining three depth layers, being D1 from the surface to $200 \mathrm{~m}$, D2 from 200 to $1000 \mathrm{~m}$ and D3 from $1000 \mathrm{~m}$ to the sea floor. In each sector, the biases are notably reduced by 46 to $99 \%$, indicating that the model output of the Hydro run is much closer to the observations than the initial Standard run. The smallest biases are found in both basins below $1000 \mathrm{~m}$, indicating that the model now produces a realistic deep east-west gradient. Almost all correlation coefficients increase, in some cases however just moving from an anticorrelation to no correlation. The D2 depth stratum in the east basin shows the highest correlation $(R=0.76)$ due to the new ligand parameterisation, followed by D1 in the east basin with $R=0.45$. The improvement in the deep layer was obtained by examining the effect of scavenging on dust at depth, which first introduced an interbasin gradient. Additionally, considering the hydrothermal $\mathrm{dFe}$ input enabled a better agreement around $45^{\circ} \mathrm{W}$. Here, the relative standard deviation $(\sigma(o b s) / \sigma(m o d))$ in the east and west basins is reduced in the Hydro run by 82 and $68 \%$, respectively, pointing out that the solution for the too homogenous $\mathrm{dFe}$ distribution in the model has come closer.

\subsection{Surface dFe}

Saharan dust outbreaks occur episodically and their trajectories change with the seasonal and latitudinal fluctuations of the Intertropical Convergence Zone (Chiapello et al. 1995), affecting surface dFe concentration. Available measurements (Tagliabue et al. 2012; Schlitzer et al. 2018) between $10^{\circ} \mathrm{N}$ and $40^{\circ} \mathrm{N}$ (Fig. S4 in Online Resource) show strong variability, both with longitudinal location and the month of sampling (Fig. 9). The data were compared with $\mathrm{dFe}$ output from the Standard run, the Dust run and the Scav Phyto 2 run, those runs which have shown to mostly affect the surface concentration. In each run, we considered the monthly $\mathrm{dFe}$ minimum and maximum within the latitude band from 10 to $40^{\circ} \mathrm{N}$. The observations should lay in the range of latitudinal-temporal variability defined by the minimum and maximum modelled $\mathrm{dFe}$.

The Standard run maximum (Fig. 9) has low dFe values at the American coast, an increase in the open ocean, a decrease around ca. $23^{\circ} \mathrm{W}$ and very high $\mathrm{dFe}$ value between $20^{\circ} \mathrm{W}$ and the African continent.

The effect of dust scavenging (Dust run) depends on the relative amount of biogenic and lithogenic particles. Close to the American coast, the biological productivity is comparatively high and dust deposition is small; thus, the Dust run reduces dFe by only $15 \%$ (Fig. 9). The dFe 
Table 3 Model statistics: bias $\left(\mathrm{nmol} \mathrm{L}^{-1}\right)$ and correlation coefficient $(R)$ between the observed and modelled dFe in the Standard run and the Hydro run

\begin{tabular}{lllll}
\hline Sector & Bias Standard & Bias Hydro & R Standard & R Hydro \\
\hline ALL & 0.39 & 0.11 & -0.26 & 0.25 \\
W D1 & 0.52 & 0.09 & 0.54 & 0.45 \\
E D1 & 1.17 & 0.40 & -0.16 & 0.17 \\
W D2 & 0.46 & 0.25 & -0.75 & 0.15 \\
E D2 & 0.21 & 0.06 & -0.14 & 0.76 \\
W D3 & 0.17 & 0.002 & -0.26 & 0.30 \\
E D3 & 0.27 & 0.03 & -0.46 & -0.20 \\
\hline
\end{tabular}

$W$, west of $45^{\circ} \mathrm{W} ; E$, east of $45^{\circ} \mathrm{W} ; D 1,0-200 \mathrm{~m} ; D 2,200-1000 \mathrm{~m} ; D 3,1000-6000 \mathrm{~m}$

concentration in the subtropical gyre between $25^{\circ} \mathrm{W}$ and $65^{\circ} \mathrm{W}$, where biology is weak, is reduced by $45 \%$ and the maximum east of $20^{\circ} \mathrm{W}$, where productivity and dust deposition are both high, is reduced by $25 \%$.

Adding variable ligands and scavenging on phytoplankton (Scav Phyto 2 run) (Fig. 9), further scales down the maximum $\mathrm{dFe}$ concentration in the region by $14 \%$ in the west, $32 \%$ in the centre and $13 \%$ in the east, where scavenging is $10 \%$ less than that in the centre.

The monthly minima do not differ much in the three model runs.

Both changes bring the model much closer to the measured surface values, even though the model still overestimates the $\mathrm{dFe}$ concentration directly under the Saharan dust plume. A reason could be that our model does not include a direct removal of $\mathrm{dFe}$ via 'colloidal pumping' (Honeyman and Santschi 1989), i.e. the fast aggregation of colloidal particles with larger particles. Aerosol Fe is predominantly released into the colloidal size fraction (Section 2) (Fitzsimmons et al. 2015b). Therefore, we could be missing an important loss process of dFe. Furthermore, in our model, the input from dust deposition is calculated with an uniform solubility of $2 \%$, while it has been shown that Saharan's dust solubility is smaller because of its mineralogy and small anthropogenic contribution (Bonnet and Guieu 2004). Considering a variable solubility in the model might further improve the model-data agreement.

\subsection{Subsurface dFe}

The GA03 exhibits very low subsurface $\mathrm{dFe}$ concentrations at depths between 100 and $200 \mathrm{~m}$ and extending to $700 \mathrm{~m}$ in the western basin, implying a remarkably strong $\mathrm{dFe}$ sink which draws down almost all $\mathrm{dFe}$ deposited at the surface. The decrease of dFe to low concentrations between 30 and $70 \mathrm{~m}$ is associated with the DCM and is explained by removal mechanism as a strong biological uptake and scavenging on phytoplankton (and maybe colloidal aggregation which however is not included in our model). Below the DCM, we would expect an increase in $\mathrm{dFe}$;
Fig. 9 Latitudinal-temporal variability of observed and modelled surface dFe. For each model run (Standard, Dust and Scav Phyto 2), 12 lines represent the monthly maximum and further 12 lines represent the monthly minimum

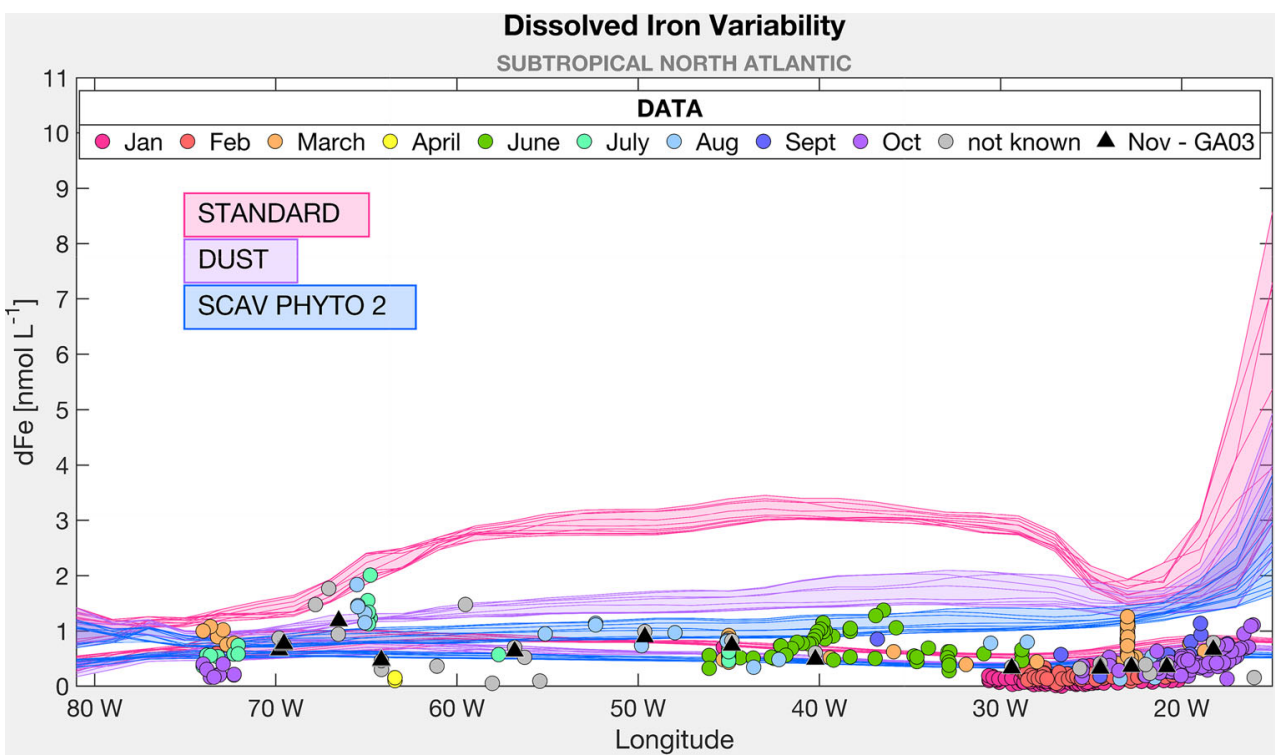


however, west of $35^{\circ} \mathrm{W}$, the $\mathrm{dFe}$ concentrations remain low until ca. $700 \mathrm{~m}$. Bergquist and Boyle (2006) point out this broad $\mathrm{dFe}$ minimum to be characteristic for $\mathrm{dFe}$ profiles in the North Atlantic subtropical gyre and to be enclosed in a pycnocline as deep as $700 \mathrm{~m}$. Jenkins et al. (2015) show that the thermocline waters in the GA03 section lie between the winter mixed layer and the density boundary $\sigma_{0}=27 \mathrm{~kg} \mathrm{~m}^{-3}$, which separates them from the intermediate water masses. The $\sigma_{0}$ density boundary lies roughly between 600 and $800 \mathrm{~m}$. Along the section, $90 \%$ of the thermocline waters' end member water types consists of the North Atlantic Central Waters. At the outcrop of this water $\left(\mathrm{ca} .40^{\circ} \mathrm{N}\right)$ (Tchernia 1980), dust deposition is lower, and therefore water masses have potentially lower surface $\mathrm{dFe}$ values. This water then spreads along isopycnals towards the subtropics.

In the Hydro run (Fig. 7), the subsurface dFe minimum is present but only extends to a depth of ca. $200 \mathrm{~m}$. Below, dFe increases, instead of maintaining very low observed values. In the model, the isopycnal $\sigma_{0}=27 \mathrm{~kg} \mathrm{~m}^{-3}$ along GA03 is found at similar depths as in Jenkins et al. (2015), thus the modelled water mass is formed approximately at the same latitude as the observed. Despite the dust deposition in the North Atlantic is relatively low in the model, the modelled $\mathrm{dFe}$ concentrations north of GA03 section along the isopycnal (Fig. 10) are too high compared to the observed values along GA02 (Rijkenberg et al. 2014). Most likely, this is due to a surface northward advective transport from the subtropical gyre characterised by too high $\mathrm{dFe}$ under the dust plume. Other explanation could be a still too shallow remineralisation, a too low consumption by phytoplankton and higher Fe:C. The first was tested in the $V S$ run and the latter is discussed in Section 2 in Online Resource. Fitzsimmons et al. (2013) derived $\mathrm{Fe}: \mathrm{C}$ rations ranging between 9.6 and $12.4 \mu \mathrm{mol} / \mathrm{mol}$, which agrees with previous findings by Bergquist and Boyle (2006) $(11 \mu \mathrm{mol} / \mathrm{mol})$. The enriched Fe:C ratio in the tropical North Atlantic could reflect "luxury uptake" by phytoplankton, thus the storage of $\mathrm{dFe}$ for future $\mathrm{dFe}$-poor times (Fitzsimmons et al. 2013). By any means, the southward transport of these water masses along the isopycnal leads to an overestimation of the subsurface $\mathrm{dFe}$ concentration in our model.

\subsection{Intermediate and deep dFe}

In the intermediate and deep waters, the $\mathrm{dFe}$ concentration is determined by remineralisation, ligand concentration, transported water enriched with sedimentary $\mathrm{dFe}$ and hydrothermal $\mathrm{dFe}$ input. Additionally, we observed that scavenging on lithogenic particles, which has mostly been analysed in relation to surface $\mathrm{dFe}$ distribution (Ye and Völker 2017), also has a great effect at depth. Indeed, in the Dust run, the very homogenous $\mathrm{dFe}$ concentrations below $1000 \mathrm{~m}$ in the Standard run are replaced by an inter-basin gradient. Scavenging at depth is smaller than at the surface right under the dust plume; however, the relative change is maximal in the deep waters in the east basin. Here, the $\mathrm{dFe}$ decreases by three orders of magnitude because considering both organic and lithogenic particles, we have now 8000 times more mass available in the deep ocean for the $\mathrm{dFe}$ to scavenge on. As a consequence, the produced $\mathrm{dFe}$ concentrations in the deep east basin are too low compared
Fig. 10 Modelled and observed $\mathrm{dFe}$ concentrations along the isopycnal $\sigma_{0}=27 \mathrm{~kg} \mathrm{~m}^{-3}$

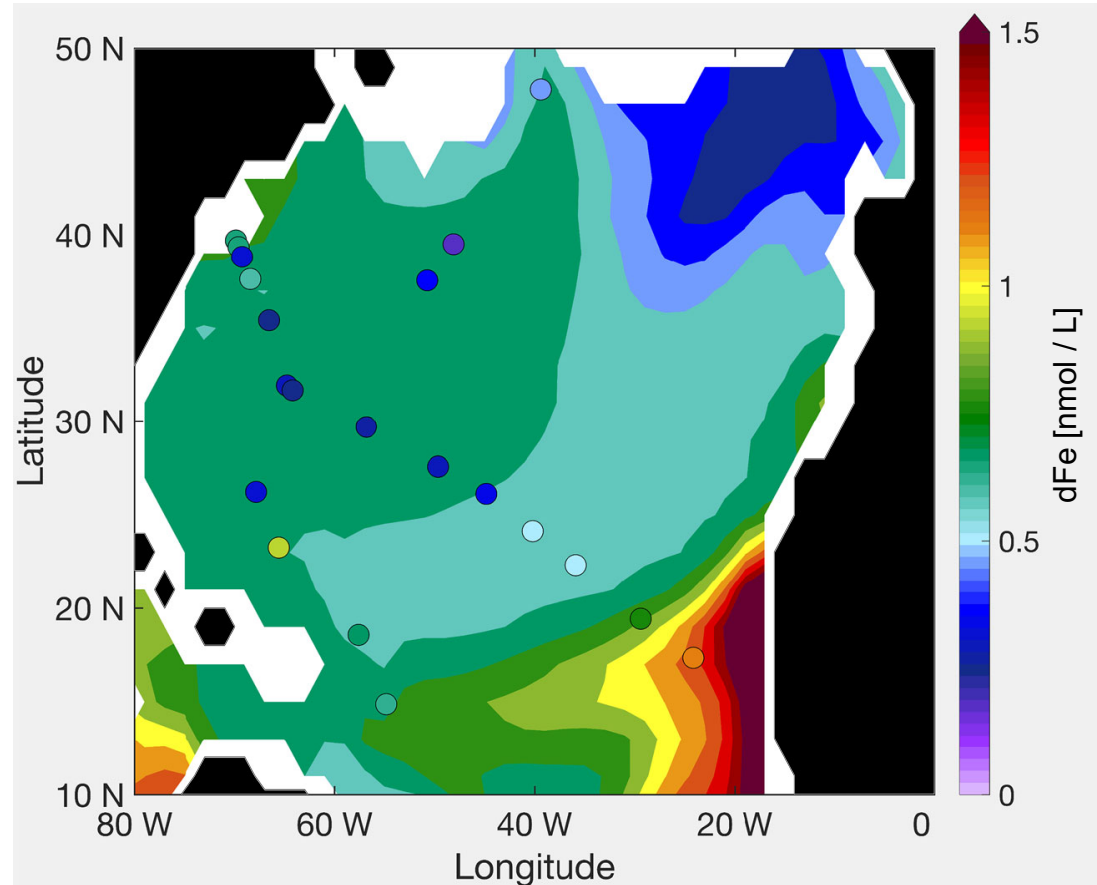


with the observations (Fig. 3). In the AOU-Lig run and the VS run, we observe how additional ligands and fewer particles at depth, respectively, counteracted this trend. (1) While being able to reproduce the $\mathrm{dFe}$ vertical maximum close to Cape Verde is not new, the combined effect of a AOU-based ligand distribution and the scavenging on lithogenic particles on the $\mathrm{dFe}$ distribution at depth was not yet addressed. As a matter of fact, in the AOU-Lig run, the higher ligand concentration in the deep east basin compared with the deep west basis partially compensates the too strong east-west gradient produced by dust scavenging. (2) An interesting side effect in the VS run is that fewer dust particles are found in the deep ocean. In fact, dust particles either sink slowly on their own or they aggregate with biological particles and sink with them, faster. When we increase the sinking velocity of detritus, its concentration near the surface decreases. Consequently, there is less aggregation. The existing large lithogenic aggregates sink faster out of the water column, reducing the amount of small particles released by disaggregation at depth. This has repercussions on scavenging and remineralisation.

In conclusion, we observe that in this study the $\mathrm{dFe}$ cycle in the deep Atlantic shifted from being similarly influenced by remineralisation and scavenging in the initial Standard run to a dominance of scavenging in the final Hydro run. In Fig. S2 WD3 and ED3, we observe that in the Standard run the integrated release of $\mathrm{dFe}$ from remineralisation and the integrated loss of dFe by scavenging are of the same order of magnitude in both basins. On the other hand, in the Hydro run, while remineralisation remained of similar strength, the scavenging loss increased drastically. This relative increase was more pronounced in the east basin (ED3) compared with the west basin (WD3), leading to lower $\mathrm{dFe}$ concentrations in the east, thus to an inter-basin $\mathrm{dFe}$ gradient.

In Section 4.6, we mentioned that switching on the hydrothermal $\mathrm{dFe}$ source for 1000 years results in a distortion of the dFe distribution at depth. An additional preformed $\mathrm{dFe}$ signal transported from the Southern Ocean and the Indian Ocean induces a general increase of $\mathrm{dFe}$ concentration below $500 \mathrm{~m}$. This increase of $\mathrm{dFe}$ is the result of the interaction of ligands and hydrothermalism in other regions of the global ocean. In our model, hydrothermal dFe is stabilised through the ligands parameterised from AOU. As the iron-binding ligands released by remineralisation are themselves prone to bacterial drawdown, the relationship between ligands and AOU is expected to be different in younger and older waters (like in the deep Atlantic and Pacific, respectively) since in younger waters the ligands have not yet been degraded. Thus, as mentioned before, the ligand parameterisation used here is only applicable to the Atlantic Ocean as it gives too high concentrations in the deep Pacific Ocean. This leads to a too strong stabilisation of hydrothermal $\mathrm{dFe}$ in the Pacific, which affects the $\mathrm{dFe}$ distribution globally after too long model integration. Since the $\mathrm{dFe}$ distribution in other ocean basins is beyond the scope of this regional study, we just acknowledge this bias.

\section{Conclusion}

In this paper, we explain step by step which main processes are influencing the $\mathrm{dFe}$ distribution in the Subtropical North Atlantic, a region characterised by high dust deposition. The model outputs were compared with the $\mathrm{dFe}$ values obtained along GEOTRACES GA03 cruise (Sedwick et al. 2015). Starting from a fairly standard set of parameters, including new processes and parameterisations, we found out that several processes can explain the main features, thus supporting their importance in the regional $\mathrm{dFe}$ distribution. This helps to better reproduce the observations along the GA03 cruise. Scavenging on dust reduces the excess $\mathrm{dFe}$ at the surface and produces a deep east-west gradient, replacing the homogeneous deep $\mathrm{dFe}$ concentration. Together with scavenging on biomass, it also strengthens the shallow $\mathrm{dFe}$ minimum below the mixed layer. A non-constant ligand distribution generates the high $\mathrm{dFe}$ values in the upper $1000 \mathrm{~m}$ west of Cap Verde. Faster sinking particles deepen the remineralisation maximum affecting $\mathrm{dFe}$ concentration throughout the water column. A hydrothermal signal was included for completeness. Though the model refinements clearly improve the agreement between modelled and observed dFe distributions, further work is required in the development of the model.

As a consequence of the complexity of the Fe cycle, models designed for capturing the main features of the global $\mathrm{dFe}$ distribution may fail to reproduce regional features. The processes at play in the Fe cycle influence each other in a way that the system is highly non-linear, i.e. the changes in $\mathrm{dFe}$ caused by changes in different process parameterisations do not add linearly. This makes a full parameter-tuning exercise very difficult, explaining why our initial attempt to use the linear approach of the Green's function like in Menemenlis and Wunsch (1997) had no success. One possibility might be to use data assimilation methods, such as the adjoint method. This method has been applied to the oceanic iron cycle in steady state by Frants et al. (2016), but requires a construction of the adjoint of the model equation. Another possible solution is to work on regional scales.

This process-oriented regional study is possible thanks to fieldwork performed in the area. With data from other regions becoming available, the global validity of processes and parameterisations considered here can be assessed for future development of dFe biogeochemical models. 
Acknowledgements We thank the editor and three anonymous reviewers for their helpful and constructive suggestions for improvement of the manuscript. We thank Peter Sedwick for publishing dFe data from the GEOTRACES cruise GA03. Work presented here was made possible through the PalMod project, funded by the German Federal Ministry for Education and Research under the grant number 01LP1505C

Open Access This article is distributed under the terms of the Creative Commons Attribution 4.0 International License (http:// creativecommons.org/licenses/by/4.0/), which permits unrestricted use, distribution, and reproduction in any medium, provided you give appropriate credit to the original author(s) and the source, provide a link to the Creative Commons license, and indicate if changes were made.

\section{References}

Balistrieri L, Brewer PG, Murray JW (1981) Scavenging residence times of trace metals and surface chemistry of sinking particles in the deep ocean. Deep Sea Res Part A, https://doi.org/10.1016/01 98-0149(81)90085-6

Bennett SA, Achterberg EP, Connelly DP, Statham PJ, Fones GR, German CR (2008) The distribution and stabilisation of dissolved Fe in deep-sea hydrothermal plumes. Earth Planet Sci Lett 270(34):157-167. https://doi.org/10.1016/j.epsl.2008.01.048

Bergquist BA, Boyle EA (2006) Dissolved iron in the tropical and subtropical Atlantic Ocean. Global Biogeochem Cycles, https://doi.org/10.1029/2005GB002505

Bergquist BA, Wu J, Boyle EA (2007) Variability in oceanic dissolved iron is dominated by the colloidal fraction. Geochimica et Cosmochimica Acta, https://doi.org/10.1016/j.gca.2007.03.013

Bonnet S, Guieu C (2004) Dissolution of atmospheric iron in seawater. Geophys Res Lett, https://doi.org/10.1029/2003GL018423

Boyd PW, Ellwood MJ (2010) The biogeochemical cycle of iron in the ocean. Nat Geosci, https://doi.org/10.1038/ngeo964

Boyd PW, Watson AJ, Law CS, Abraham ER, Trull T, Murdoch R, Bakker DCE, Bowie AR, Buesseler KO, Chang H, Charette M, Croot P, Downing K, Frew R, Gall M, Hadfield M, Hall J, Harvey M, Jameson G, LaRoche J, Liddicoat M, Ling R, Maldonado MT, McKay RM, Nodder S, Pickmere S, Pridmore R, Rintoul S, Safi K, Sutton P, Strzepek R, Tanneberger K, Turner S, Waite A, Zeldis J (2000) A mesoscale phytoplankton bloom in the polar Southern Ocean stimulated by iron fertilization. Nature https://doi.org/10.1038/35037500

Boyle EA, Anderson RF, Cutter GA, Fine R, Jenkins WJ, Saito M (2015) Introduction to the U.S. GEOTRACES North Atlantic Transect (GA-03): USGT10 and USGT11 cruises. Deep-Sea Res II Top Stud Oceanogr, https://doi.org/10.1016/j.dsr2.2015.02.031

Buck KN, Sohst B, Sedwick PN (2015) The organic complexation of dissolved iron along the U.S. GEOTRACES (GA03) North Atlantic Section. Deep-Sea Res II Top Stud Oceanogr, https://doi.org/10.1016/j.dsr2.2014.11.016

Chiapello I, Bergametti G, Gomes L, Chatenet B, Dulac F, Pimenta J, Suares ES (1995) An additional low layer transport of Sahelian and Saharan dust over the north-eastern Tropical Atlantic. Geophys Res Lett, https://doi.org/10.1029/95GL03313

Conway TM, John SG (2014) Quantification of dissolved iron sources to the North Atlantic Ocean. Nature, https://doi.org/10.1038/ nature 13482

de Baar HJW, Boyd PW, Coale KH, Landry MR, Tsuda A, Assmy P, Bakker DCE, Bozec Y, Barber RT, Brzezinski MA, Buesseler
KO, Boyé M, Croot PL, Gervais F, Gorbunov MY, Harrison PJ, Hiscock WT, Laan P, Lancelot C, Law CS, Levasseur M, Marchetti A, Millero FJ, Nishioka J, Nojiri Y, van Oijen T, Riebesell U, Rijkenberg MJA, Saito H, Takeda S, Timmermans KR, Veldhuis MJW, Waite AM, Wong CS (2005) Synthesis of iron fertilization experiments: from the iron age in the age of enlightenment. J Geophys Res Ocean https://doi.org/10.1029/20 04JC002601

Elrod VA, Berelson WM, Coale KH, Johnson KS (2004) The flux of iron from continental shelf sediments: a missing source for global budgets. Geophys Res Lett, https://doi.org/10.1029/2004GL020 216

Fitzsimmons JN, Zhang R, Boyle EA (2013) Dissolved iron in the tropical North Atlantic Ocean. Mar Chem, https://doi.org/10.1016/j. marchem.2013.05.009

Fitzsimmons JN, Bundy RM, Al-Subiai SN, Barbeau KA, Boyle EA (2015a) The composition of dissolved iron in the dusty surface ocean: an exploration using size-fractionated iron-binding ligands. Mar Chem, https://doi.org/10.1016/j.marchem.2014.09.002

Fitzsimmons JN, Carrasco GG, Wu J, Roshan S, Hatta M, Measures CI, Conway TM, John SG, Boyle EA (2015b) Partitioning of dissolved iron and iron isotopes into soluble and colloidal phases along the GA03 GEOTRACES North Atlantic Transect. Deep-Sea Res II Top Stud Oceanogr, https://doi.org/10.1016/j.dsr2.2014.11. 014

Fitzsimmons JN, John SG, Marsay CM, Hoffman CL, Nicholas SL, Toner BM, German CR, Sherrell RM (2017) Iron persistence in a distal hydrothermal plume supported by dissolved-particulate exchange. Nat Geosci 10(3):195-201. https://doi.org/10.1038/ ngeo 2900

Frants M, Holzer M, DeVries T, Matear R (2016) Constraints on the global marine iron cycle from a simple inverse model. J Geophys Res Biogeoscience, https://doi.org/10.1002/2015JG003111

Garcia HE, Locarnini RA, Boyer TP, Antonov JI, Baranova OK, Zweng MM, Johnson DR (2010a) World Ocean Atlas 2009 volume 3: dissolved oxygen, apparent oxygen utilization, and oxygen saturation Levitus S (ed). NOAA atlas NESDIS 70, US government printing office, Washington, DC

Garcia HE, Locarnini RA, Boyer TP, Antonov JI, Zweng MM, Baranova OK, Johnson DR (2010b) World Ocean Atlas 2009 volume 4: nutrients (phosphate, nitrate, and silicate) Levitus $\mathrm{S}$ (ed). NOAA Atlas NESDIS 71, US Government Printing Office, Washington, DC

Geider RJ, Macintyre HL, Kana TM (2003) A dynamic regulatory model of phytoplanktonic acclimation to light, nutrients, and temperature. Limnol Oceanogr, https://doi.org/10.4319/lo.1998.43.4. 0679

Gledhill M, Buck K (2012) The organic complexation of iron in the marine environment: a review. Front Microbiol, https://doi.org/10.3389/fmicb.2012.00069

Hamme RC, Webley PW, Crawford WR, Whitney FA, DeGrandpre MD, Emerson SR, Eriksen CC, Giesbrecht KE, Gower JFR, Kavanaugh MT, Peña MA, Sabine CL, Batten SD, Coogan LA, Grundle DS, Lockwood D (2010) Volcanic ash fuels anomalous plankton bloom in subarctic northeast pacific. Geophys Res Lett 37(19), https://doi.org/10.1029/2010GL044629

Hatta M, Measures CI, Wu J, Roshan S, Fitzsimmons JN, Sedwick P, Morton P (2015) An overview of dissolved Fe and Mn distributions during the 20102011 U.S. GEOTRACES north Atlantic cruises: GEOTRACES GA03. Deep-Sea Res II Top Stud Oceanogr, https://doi.org/10.1016/j.dsr2.2014.07.005

Hauck J, Völker C, Wang T, Hoppema M, Losch M, Wolf-Gladrow DA (2013) Seasonally different carbon flux changes in the Southern Ocean in response to the southern annular mode. Glob. Biogeochem Cycles, https://doi.org/10.1002/2013GB004600 
Hohn S (2009) Coupling and decoupling of biogeochemical cycles in marine ecosystems $\mathrm{PhD}$ thesis, Universitat Bremen

Honeyman BD, Santschi PH (1989) A Brownian-pumping model for oceanic trace metal scavenging: Evidence from Th isotopes. J Marit Res, https://doi.org/10.1357/002224089785076091

Hudson RJM, Morel FMM (1989) Distinguishing between extraand intracellular iron in marine phytoplankton. Limnol Oceanogr, https://doi.org/10.4319/lo.1989.34.6.1113

Hunter KA, Leonard MR, Carpenter PD, Smith JD (1997) Aggregation of iron colloids in estuaries: a heterogeneous kinetics study using continuous mixing of river and sea waters. Colloids Surf A Physicochem Eng Asp, https://doi.org/10.1016/S0927-7757(96)03719-3

Jenkins WJ, Smethie WM, Boyle EA, Cutter GA (2015) Water mass analysis for the U.S. GEOTRACES (GA03) North Atlantic sections. Deep-Sea Res II Top Stud Oceanogr, https://doi.org/10. 1016/j.dsr2.2014.11.018

Jickells TD, An ZS, Andersen KK, Baker AR, Bergametti G, Brooks N, Cao JJ, Boyd PW, Duce RA, Hunter KA, Kawahata H, Kubilay N, laRoche J, Liss PS, Mahowald N, Prospero JM, Ridgwell AJ, Tegen I, Torres R (2005) Global iron connections between desert dust, ocean biogeochemistry, and climate. Science 308(5718):6771. https://doi.org/10.1126/science.1105959

Kriest I, Oschlies A (2008) On the treatment of particulate organic matter sinking in large-scale models of marine biogeochemical cycles. Biogeosciences (BG), https://doi.org/10.5194/bg-5-552008

Lannuzel D, Schoemann V, de Jong J, Chou L, Delille B, Becquevort $\mathrm{S}$, Tison JL (2008) Iron study during a time series in the western Weddell pack ice. Mar Chem, https://doi.org/10.1016/j.marchem. 2007.10.006

Lis H, Shaked Y, Kranzler C, Keren N, Morel FMM (2014) Iron bioavailability to phytoplankton: an empirical approach. The Isme J, https://doi.org/10.1038/ismej.2014.199

Liu X, Millero FJ (2002) The solubility of iron in seawater. Mar Chem, https://doi.org/10.1016/S0304-4203(01)00074-3

Mahowald NM, Baker AR, Bergametti G, Brooks N, Duce RA, Jickells TD, Kubilay N, Prospero JM, Tegen I (2005) Atmospheric global dust cycle and iron inputs to the ocean. Global Biogeochem Cycles, https://doi.org/10.1029/2004GB002402

Marchetti A, Maldonado MT, Lane ES, Harrison PJ (2006) Iron requirements of the pennate diatom Pseudo-nitzschia: Comparison of oceanic (high-nitrate, low-chlorophyll waters) and coastal species. Limnol Oceanogr 51(5):2092-2101. https://doi.org/10. 4319/lo.2006.51.5.2092

Marshall J, Adcroft A, Hill C, Perelman L, Heisey C (1997) A finite-volume, incompressible Navier Stokes model for studies of the ocean on parallel computers. J Geophys Res Oceans, https://doi.org/10.1029/96JC02775

Martin JH, Coale KH, Johnson KS, Fitzwater SE, Gordon RM, Tanner SJ, Hunter CN, Elrod VA, Nowicki JL, Coley TL, Barber RT, Lindley S, Watson AJ, Van Scoy K, Law CS, Liddicoat MI, Ling R, Stanton T, Stockel J, Collins C, Anderson A, Bidigare R, Ondrusek M, Latasa M, Millero FJ, Lee K, Yao W, Zhang JZ, Friederich G, Sakamoto C, Chavez F, Buck K, Kolber Z, Greene R, Falkowski P, Chisholm SW, Hoge F, Swift R, Yungel J, Turner S, Nightingale P, Hatton A, Liss P, Tindale NW (1994) Testing the iron hypothesis in ecosystems of the equatorial Pacific Ocean. Nature, https://doi.org/10.1038/371123a0

Menemenlis D, Wunsch C (1997) Linearization of an Oceanic General Circulation Model for Data Assimilation and Climate Studies. J Atmos Ocean Technol, https://doi.org/10.1175/1520-0426(1997) 014<1420:LOAOGC > 2.0.CO;2

Misumi K, Lindsay K, Moore JK, Doney SC, Tsumune D, Yoshida Y. (2013) Humic substances may control dissolved iron distributions in the global ocean: Implications from numerical simulations. Global Biogeochem Cycles, https://doi.org/10.1002/gbc.20039
Moore J, Doney SC, Glover DM, Fung IY (2001) Iron cycling and nutrient-limitation patterns in surface waters of the World Ocean. Deep-Sea Res II Top Stud Oceanogr, https://doi.org/10.1016/ S0967-0645(01)00109-6

Nicol S, Bowie A, Jarman S, Lannuzel D, Meiners KM, Van Der Merwe P. (2010) Southern Ocean iron fertilization by baleen whales and Antarctic krill. Fish Fish 11(2):203-209. https://doi.org/10.1111/j.1467-2979.2010.00356.x

Parekh P, Follows MJ, Boyle E (2004) Modeling the global ocean iron cycle. Global Biogeochem Cycles, https://doi.org/10.1029/2003 GB002061

Pham ALD, Ito T (2018) Formation and Maintenance of the GEOTRACES subsurface-dissolved iron maxima in an ocean biogeochemistry model. Global Biogeochem Cycles, https://doi.org/10. 1029/2017GB005852

Raiswell R, Benning LG, Tranter M, Tulaczyk S. (2008) Bioavailable iron in the Southern Ocean: the significance of the iceberg conveyor belt. Geochem Trans, https://doi.org/10.1186/1467-48669-7

Raven JA, Evans MCW, Korb RE (1999) The role of trace metals in photosynthetic electron transport in $\mathrm{O}_{2}$-evolving organisms. Photosynth Res 60(2):111-150. https://doi.org/10.1023/A:10062 82714942

Resing JA, Sedwick PN, German CR, Jenkins WJ, Moffett JW, Sohst BM, Tagliabue A. (2015) Basin-scale transport of hydrothermal dissolved metals across the South Pacific Ocean. Nature, https://doi.org/10.1038/nature14577

Rijkenberg MJA, Steigenberger S, Powell CF, Haren H, Patey MD, Baker AR, Achterberg EP (2012) Fluxes and distribution of dissolved iron in the eastern (sub-) tropical North Atlantic Ocean. Global Biogeochem Cycles, https://doi.org/10.1029/2011GB00 4264

Rijkenberg MJA, Middag R, Laan P, Gerringa LJA, van Aken HM, Schoemann V, de Jong JTM, de Baar HJW (2014) The distribution of dissolved iron in the west atlantic ocean. PLOS ONE, https://doi.org/10.1371/journal.pone.0101323

Schlitzer, R, Anderson, RF, Dodas, EM, Lohan, M, Geibert, W, Tagliabue, A, Bowie, A, Jeandel, C, Maldonado, MT, Landing, WM, Cockwell, D, Abadie, C, Abouchami, W, Achterberg, EP, Agather, A, Aguliar-Islas, A, van Aken, HM, Andersen, M, Archer, C, Auro, M, de Baar, HJ, Baars, O, Baker, AR, Bakker, K, Basak, C, Baskaran, M, Bates, NR, Bauch, D, van Beek, P, Behrens, MK, Black, E, Bluhm, K, Bopp, L, Bouman, H, Bowman, K, Bown, J, Boyd, P, Boye, M, Boyle, EA, Branellec, $\mathrm{P}$ Bridgestock, L, Brissebrat, G, Browning, T, Bruland, KW, Brumsack, HJ, Brzezinski, M, Buck, CS, Buck, KN, Buesseler, K, Bull, A, Butler, E, Cai, P, Mor, PC, Cardinal, D, Carlson, C, Carrasco, G, Casacuberta, N, Casciotti, KL, Castrillejo, M, Chamizo, E, Chance, R, Charette, MA, Chaves, JE, Cheng, H, Chever, F, Christl, M, Church, TM, Closset, I, Colman, A, Conway, TM, Cossa, D, Croot, P, Cullen, JT, Cutter, GA, Daniels, C, Dehairs, F, Deng, F, Dieu, HT, Duggan, B, Dulaquais, G, Dumousseaud, C, Echegoyen-Sanz, Y, Edwards, RL, Ellwood, M, Fahrbach, E, Fitzsimmons, JN, Flegal, AR, Fleisher, MQ van de Flierdt, T, Frank, M, Friedrich, J Fripiat, F, Fröllje, H, Galer, SJ, Gamo, T, Ganeshram, RS, Garcia-Orellana, J, Garcia-Solsona, E, Gault-Ringold, M, George, E, Gerringa, LJ, Gilbert, M, Godoy, JM, Goldstein, SL, Gonzalez, SR, Grissom, K, Hammerschmidt, C, Hartman, A, Hassler, CS, Hathorne, EC, Hatta, M, Hawco, N, Hayes, CT, Heimbürger, LE, Helgoe, J, Heller, M, Henderson, GM, Henderson, PB, van Heuven, S, Ho, P, Horner, TJ, Hsieh, YT, Huang, KF, Humphreys, MP Isshiki, K, Jacquot, JE, Janssen, DJ, Jenkins, WJ, John, S, Jones, EM, Jones, JL, Kadko, DC, Kayser, R, Kenna, TC, Khondoker, R, Kim, T, Kipp, L, Klar, JK, Klunder, M, Kretschmer, S Kumamoto, Y, Laan, P, Labatut, M, 
Lacan, F, Lam, PJ, Lambelet, M, Lamborg, CH Moigne, FAL, Roy, EL, Lechtenfeld, OJ, Lee, JM, Lherminier, P, Little, S, LópezLora, M, Lu, Y, Masque, P, Mawji, E, Mcclain, CR, Measures, C, Mehic, S, Barraqueta, JLM, van der Merwe, P, Middag, R, Mieruch, S, Milne, A, Minami, T, Moffett, JW, Moncoiffe, G, Moore, WS Morris, PJ, Morton, PL, Nakaguchi, Y, Nakayama, N, Niedermiller, J, Nishioka, J, Nishiuchi, A, Noble, A, Obata, H Ober, S, Ohnemus, DC, van Ooijen, J, O'Sullivan, J, Owens, S, Pahnke, K Paul, M, Pavia, F, Pena, LD, Peters, B Planchon, F, Planquette, H, Pradoux, C, Puigcorbé, V, Quay, P Queroue, F, Radic, A, Rauschenberg, S, Rehkämper, M, Rember, R Remenyi, T, Resing, JA, Rickli, J, Rigaud, S, Rijkenberg, MJ, Rintoul, S, Robinson, LF, Roca-Martí, M Rodellas, V, Roeske, T, Rolison, JM, Rosenberg, M, Roshan, S, van der Loeff, MMR Ryabenko, E, Saito, MA, Salt, LA, Sanial, V, Sarthou, G, Schallenberg, C, Schauer, U, Scher, H, Schlosser, C, Schnetger, B, Scott, P, Sedwick, PN, Semiletov, I Shelley, R, Sherrell, RM, Shiller, AM, Sigman, DM, Singh, SK, Slagter, HA, Slater, E Smethie, WM, Snaith, H, Sohrin, Y, Sohst, B, Sonke, JE, Speich, S, Steinfeldt, R, Stewart, G, Stichel, T, Stirling, CH, Stutsman, J, Swarr, GJ, Swift, JH, Thomas, A, Thorne, K, Till, CP Till, R, Townsend, AT, Townsend, E, Tuerena, R, Twining, BS, Vance, D, Velazquez, S, Venchiarutti, C, Villa-Alfageme, M, Vivancos, SM, Voelker, AH, Wake, B, Warner, MJ, Watson, R, van Weerlee, E, Weigand, MA, Weinstein, Y, Weiss, D, Wisotzki, A, Woodward, EMS, Wu, J, Wu, Y, Wuttig, K, Wyatt, N, Xiang, Y, Xie, RC, Xue, Z, Yoshikawa, H, Zhang, J, Zhang, P, Zhao, Y, Zheng, L, Zheng, $\mathrm{XY}$, Zieringer, M, Zimmer, LA, Ziveri, P, Zunino, P, Zurbrick, C (2018). The GEOTRACES intermediate data product 2017. Chem Geol, https://doi.org/10.1016/j.chemgeo.2018.05.040

Sedwick PN, Church TM, Bowie AR, Marsay CM, Ussher SJ, Achilles KM, Lethaby PJ, Johnson RJ, Sarin MM, McGillicuddy DJ (2005) Iron in the Sargasso Sea (Bermuda Atlantic Time-series
Study region) during summer: Eolian imprint, spatiotemporal variability, and ecological implications. Global Biogeochem Cycles, https://doi.org/10.1029/2004GB002445

Sedwick PN, Sohst BM, Ussher SJ, Bowie AR (2015) A zonal picture of the water column distribution of dissolved iron(II) during the U.S. GEOTRACES North Atlantic transect cruise (GEOTRACES GA03). Deep-Sea Res II Top Stud Oceanogr, https://doi.org/10.1016/j.dsr2.2014.11.004

Tagliabue A, Bopp L, Dutay J, Bowie AR, Chever F, Jean-Baptiste P, Bucciarelli E, Lannuzel D, Remenyi T, Sarthou G, Aumont O, Gehlen M, Jeandel C (2010) Hydrothermal contribution to the oceanic dissolved iron inventory. Nature Geoscience, https://doi.org/10.1038/ngeo818

Tagliabue A, Mtshali T, Aumont O, Bowie AR, Klunder MB, Roychoudhury AN, Swart S. (2012) A global compilation of dissolved iron measurements: focus on distributions and processes in the Southern Ocean. Biogeosciences, https://doi.org/10.5194/bg-92333-2012

Tagliabue A, Aumont O, DeAth R, Dunne JP, Dutkiewicz S, Galbraith E, Misumi K, Moore JK, Ridgwell A, Sherman E, Stock C, Vichi M, Völker C, Yool A (2016) How well do global ocean biogeochemistry models simulate dissolved iron distributions? Global Biogeochem Cycles, https://doi.org/10.1002/2015GB005 289

Tchernia P (1980) Descriptive regional oceanography. Elsevier, New York

Ye Y, Völker C (2017) On the role of dust-deposited lithogenic particles for iron cycling in the tropical and subtropical atlantic. Global Biogeochem Cycles, https://doi.org/10.1002/2017GB005663

Yücel M, Gartman A, Chan CS, Luther GW III (2011) Hydrothermal vents as a kinetically stable source of iron-sulphide-bearing nanoparticles to the ocean. Nat Geosci 4:367-371. https://doi.org/ 10.1038/ngeo1148 